\title{
North-south palaeohydrological contrasts in the central Mediterranean during the Holocene: tentative synthesis and working hypotheses
}

M. Magny ${ }^{1}$, N. Combourieu-Nebout ${ }^{2}$, J. L. de Beaulieu ${ }^{3}$, V. Bout-Roumazeilles ${ }^{4}$, D. Colombaroli ${ }^{5}$, S. Desprat ${ }^{6}$,

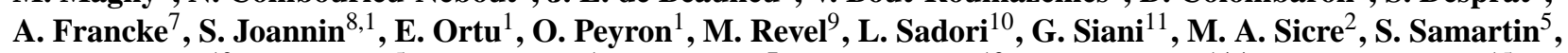
A. Simonneau ${ }^{12}$, W. Tinner ${ }^{5}$, B. Vannière ${ }^{1}$, B. Wagner ${ }^{7}$, G. Zanchetta ${ }^{13}$, F. Anselmetti ${ }^{14, *}$, E. Brugiapaglia ${ }^{15}$, E. Chapron $^{12}$, M. Debret ${ }^{16}$, M. Desmet ${ }^{12,17}$, J. Didier ${ }^{1}$, L. Essallami ${ }^{18}$, D. Galop ${ }^{19}$, A. Gilli ${ }^{20}$, J. N. Haas ${ }^{21}$, N. Kallel ${ }^{22}$, L. Millet ${ }^{1}$, A. Stock ${ }^{1}$, J. L. Turon ${ }^{6}$, and S. Wirth ${ }^{20}$

${ }^{1}$ CNRS-UMR6249, Laboratoire Chrono-Environnement, UFR des Sciences et Techniques, 16 Route de Gray, 25030 Besançon, France

${ }^{2}$ CNRS-UMR8212, Laboratoire des Sciences du Climate et de l'Environnement (LSCE)-Gif-sur-Yvette, France

${ }^{3}$ CNRS-UMR7263-IMBE, Université Paul Cézanne, Aix-en-Provence, France

${ }^{4}$ CNRS-UMR8217, Géosystèmes, Université de Lille 1, 59655, Villeneuve d'Ascq, France

${ }^{5}$ Oeschger Center for Climate Change Research and Insitute of Plant Sciences, University of Bern, Altenbergrain 21, 3013 Bern, Switzerland

${ }^{6}$ CNRS-UMR5808-Ecole Pratique des Hautes Etudes, Environnements et Paléoenviuronements Océaniques, Université de Bordeaux 1, 33405 Talence, France

${ }^{7}$ University of Cologne, Institute for Geology and Mineralogy, Cologne, Germany

${ }^{8}$ CNRS-USR3124 Maison des Sciences de l'Homme et de l'Environnement (MSHE) Ledoux, Besançon, France

${ }^{9}$ Géosciences Azur, Observatoire Océanologique, La Darse, BP 48, 06235 Villefranche/Mer, France

${ }^{10}$ Dipartimento di Biologia Ambientale, Università di Roma "La Sapienza", Piazzale Aldo Moro 5, 00185 Roma, Italy

${ }^{11}$ CNRS-UMR8148 IDES, Département des Sciences de la Terre, Université Paris Sud, 91405 Orsay, France

${ }^{12}$ CNRS-UMR7327 ISTO, Université d'Orléans, BRGM, 1A Rue de la Férollerie, 45071 Orléans, France

${ }^{13}$ Dipartimento di Scienze della Terra, Via S. Maria 53, 56126 Pisa, Italy

${ }^{14}$ Eawag, Department of Surface Waters, Überlandstrasse 133, 8600 Dübendorf, Switzerland

${ }^{15}$ Dipartimento di Scienze Animali, Vegetali e dell'Ambiente, Università degli Studi del Molise, Campobasso, Italy

${ }^{16}$ CNRS-UMR 6143 M2C, Universités de Caen Basse-Normandie et Rouen, 14000 Caen, France

${ }^{17}$ GéoHydrosystèmes Continentaux, EA6293, Université F. Rabelais de Tours, Département Géosciences-Environnement, Faculté des Sciences et Techniques, Parc de Grandmont, 37200 Tours, France

${ }^{18}$ Université de Gabès, Faculté des Sciences de Gabès, Gabès, Tunisia

${ }^{19}$ CNRS-UMR5602 GEODE, Maison de la Recherche de l'Université du Mirail, Toulouse, France

${ }^{20}$ Geological Institute, ETH Zürich, Zürich, Switzerland

${ }^{21}$ Insitut für Botanik, Universität Innsbruck, Innsbruck, Austria

${ }^{22}$ Faculté des Sciences de Sfax, Unité GEOGLOB, Route de Soukra, BP 802, 3038 Sfax, Tunisia

*current address: Insitute of Geological Sciences, University of Bern, Baltzerstrasse 1-3, 3012 Bern, Switzerland

Correspondence to: M. Magny (michel.magny@univ-fcomte.fr)

Received: 26 March 2013 - Published in Clim. Past Discuss.: 5 April 2013

Revised: 21 June 2013 - Accepted: 22 July 2013 - Published: 2 September 2013 
Abstract. On the basis of a multi-proxy approach and a strategy combining lacustrine and marine records along a northsouth transect, data collected in the central Mediterranean within the framework of a collaborative project have led to reconstruction of high-resolution and well-dated palaeohydrological records and to assessment of their spatial and temporal coherency. Contrasting patterns of palaeohydrological changes have been evidenced in the central Mediterranean: south (north) of around $40^{\circ} \mathrm{N}$ of latitude, the middle part of the Holocene was characterised by lake-level maxima (minima), during an interval dated to ca. 10300-4500 cal BP to the south and 9000-4500 cal BP to the north. Available data suggest that these contrasting palaeohydrological patterns operated throughout the Holocene, both on millennial and centennial scales. Regarding precipitation seasonality, maximum humidity in the central Mediterranean during the middle part of the Holocene was characterised by humid winters and dry summers north of ca. $40^{\circ} \mathrm{N}$, and humid winters and summers south of ca. $40^{\circ} \mathrm{N}$. This may explain an apparent conflict between palaeoclimatic records depending on the proxies used for reconstruction as well as the synchronous expansion of tree species taxa with contrasting climatic requirements. In addition, south of ca. $40^{\circ} \mathrm{N}$, the first millennium of the Holocene was characterised by very dry climatic conditions not only in the eastern, but also in the central- and the western Mediterranean zones as reflected by low lake levels and delayed reforestation. These results suggest that, in addition to the influence of the Nile discharge reinforced by the African monsoon, the deposition of Sapropel 1 has been favoured (1) by an increase in winter precipitation in the northern Mediterranean borderlands, and (2) by an increase in winter and summer precipitation in the southern Mediterranean area. The climate reversal following the Holocene climate optimum appears to have been punctuated by two major climate changes around 7500 and $4500 \mathrm{cal} \mathrm{BP}$.

In the central Mediterranean, the Holocene palaeohydrological changes developed in response to a combination of orbital, ice-sheet and solar forcing factors. The maximum humidity interval in the south-central Mediterranean started ca. $10300 \mathrm{cal} \mathrm{BP}$, in correlation with the decline (1) of the possible blocking effects of the North Atlantic anticyclone linked to maximum insolation, and/or (2) of the influence of the remnant ice sheets and fresh water forcing in the North Atlantic Ocean. In the north-central Mediterranean, the lake-level minimum interval began only around $9000 \mathrm{cal}$ BP when the Fennoscandian ice sheet disappeared and a prevailing positive NAO-(North Atlantic Oscillation) type circulation developed in the North Atlantic area. The major palaeohydrological oscillation around 4500$4000 \mathrm{cal}$ BP may be a non-linear response to the gradual decrease in insolation, with additional key seasonal and interhemispheric changes. On a centennial scale, the successive climatic events which punctuated the entire Holocene in the central Mediterranean coincided with cooling events associated with deglacial outbursts in the North Atlantic area and decreases in solar activity during the interval 11700$7000 \mathrm{cal} \mathrm{BP}$, and to a possible combination of NAO-type circulation and solar forcing since ca. $7000 \mathrm{cal} \mathrm{BP}$ onwards. Thus, regarding the centennial-scale climatic oscillations, the Mediterranean Basin appears to have been strongly linked to the North Atlantic area and affected by solar activity over the entire Holocene.

In addition to model experiments, a better understanding of forcing factors and past atmospheric circulation patterns behind the Holocene palaeohydrological changes in the Mediterranean area will require further investigation to establish additional high-resolution and well-dated records in selected locations around the Mediterranean Basin and in adjacent regions. Special attention should be paid to greater precision in the reconstruction, on millennial and centennial timescales, of changes in the latitudinal location of the limit between the northern and southern palaeohydrological Mediterranean sectors, depending on (1) the intensity and/or characteristics of climatic periods/oscillations (e.g. Holocene thermal maximum versus Neoglacial, as well as, for instance, the $8.2 \mathrm{ka}$ event versus the $4 \mathrm{ka}$ event or the Little Ice Age); and (2) on varying geographical conditions from the western to the eastern Mediterranean areas (longitudinal gradients). Finally, on the basis of projects using strategically located study sites, there is a need to explore possible influences of other general atmospheric circulation patterns than NAO, such as the East Atlantic-West Russian or North SeaCaspian patterns, in explaining the apparent complexity of palaeoclimatic (palaeohydrological) Holocene records from the Mediterranean area.

\section{Introduction}

At the interface between the European temperate and the African tropical zones, the Mediterranean area appears to be very sensitive to even low-amplitude variations in the hydrological cycle. This transitional zone is influenced by tropical circulation cells within the subtropical anticyclone belt and associated aridity, as well as by the mid-latitude westerlies and cyclogenesis (Tzedakis et al., 2009). This results in a marked precipitation seasonality that is crucial for both Mediterranean ecosystems and societies. Climate change projections over the Mediterranean show a pronounced decrease in precipitation and an increase in temperature especially during the summer season (Giorgi and Lionello, 2008), with considerable impact on water resources and consequently on biodiversity and human activities. Thus, there is an urgent need for a deeper understanding of past climatic changes and their associated palaeohydrological variations in the Mediterranean area.

Over the last two decades, using various proxies and strategies, several studies have attempted to reconstruct palaeohydrological variations in the Mediterranean area over the entire Holocene. A first synthesis was proposed in 1993 by 


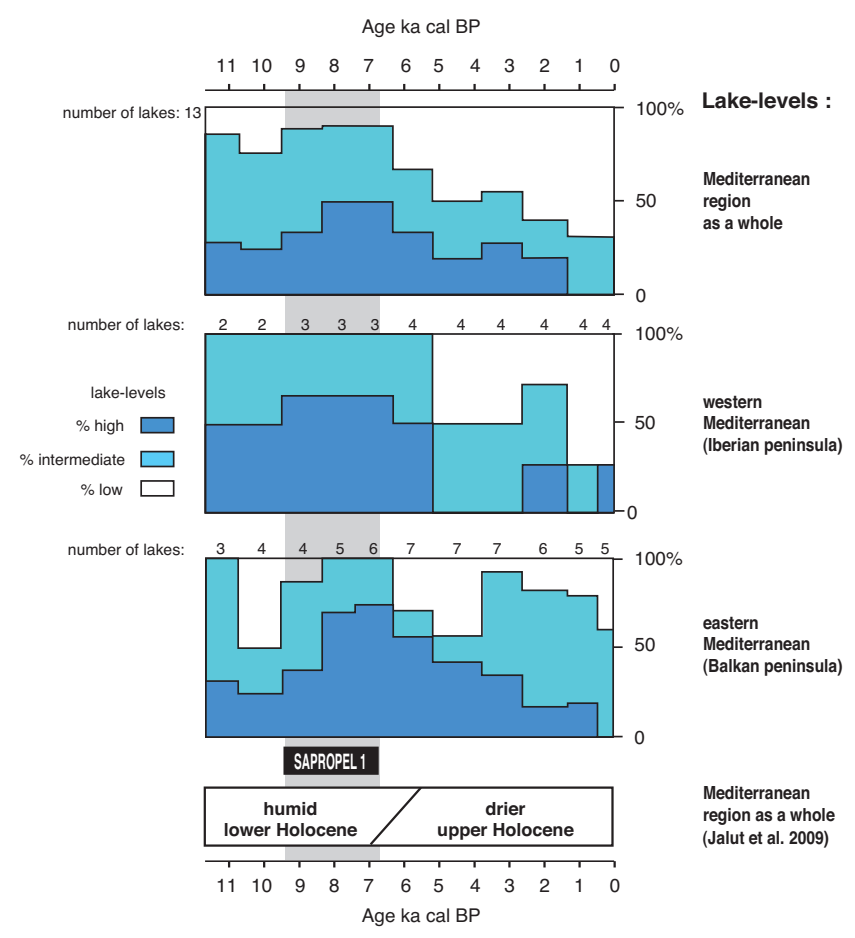

Fig. 1. Holocene changes in lake-level status and humidity in the Mediterranean as reconstructed by Harrison and Digerfeldt (1993) (upper three diagrams) and Jalut et al. (2009). The date of Sapropel 1 deposition in the Mediterranean was taken from Mercone et al. (2000). LC: Lake Cerin; LSP: Lake Saint-Point. TR: Tunisian rivers.

Harrison and Digerfeldt on the basis of lake-level fluctuations. Using a compilation of various proxy data from the literature, they reconstructed changes in lake status (high, intermediate, low) at $1000 \mathrm{yr}$ intervals (Fig. 1). All together, in this study the Holocene appears to be characterised by two successive periods before and after ca. $6000 \mathrm{cal} \mathrm{BP}$, i.e. the first more humid than the second. Regarding the early Holocene, the authors also pointed out an apparent opposition between relatively dry conditions in the eastern Mediterranean and greater moisture availability in the west. This general pattern was interpreted as a response to orbitallydriven changes in insolation.

More recently, on the basis of a comparison of various palaeoenvironmental (terrestrial and marine) data (e.g. lake levels, fluvial activity, pollen records, Mediterranean sea-water temperature and salinity, marine sedimentation), Jalut et al. (2000) have proposed that, in the entire circumMediterranean area, the Holocene can be divided into three periods: a lower humid Holocene $(11500-7000 \mathrm{cal} \mathrm{BP})$, a transition phase (7000-5000 cal BP), and an upper Holocene (5500 cal BP-present) characterised by an aridification. In contrast to the multiproxy approach by Jalut et al. (2000), Roberts et al. (2008) endeavoured to establish a synthetic picture of the Holocene climate and hydrology in the Mediterranean using a single proxy, i.e. stable isotopic records from lakes. They concluded that, in the early Holocene, many east Mediterranean lakes were more depleted isotopically than in recent millennia. This coincides with marine sapropel formation, both chronologically and geographically, and implies an increase in regional rainfall responsible for lower isotopic values in lakes and marine anoxia. In contrast, isotope records from western Mediterranean lakes do not show such a pattern, suggesting a possible NW-SE bipolar contrast in climate history across the Mediterranean during the Holocene. In more recent syntheses of the mid-Holocene climatic transition in the Mediterranean, Roberts et al. $(2011,2012)$ observed that both model output and proxy data suggest an east-west division in the Mediterranean climate history. Regarding the western Mediterranean, they also noted that early Holocene changes in precipitation were smaller in magnitude and less coherent spatially, and that rainfall reached a maximum during the mid-Holocene, around 6000-3000 cal BP, before declining to present-day values.

Other recent studies are also of interest within the scope of the present paper. A comparison of hydrological records led Magny et al. (2003) to propose, as a working hypothesis, that mid-latitudes between ca. $50^{\circ}$ and $43^{\circ} \mathrm{N}$ underwent wetter conditions in response to centennial-scale climate cooling phases, whereas northern and southern Europe were marked by shifts to drier climate. In this general hydrological tripartition of Europe, the latitudinal amplitude of the middle zone could have varied in relation to the thermal gradient between the high and low latitudes. Later, Giraudi et al. (2011) and Zanchetta et al. (2012) showed the key significance of the palaeohydrological oscillation around $4000 \mathrm{cal} \mathrm{BP}$ in the general climatic trajectory of the Holocene in the central Mediterranean region. In addition to these palaeohydrological studies, a thorough review by Tzedakis (2007) has pointed out the increasingly complex climatic scenarios invoked by authors to reconcile apparently conflicting data and interpretations. Among seven ambiguities in the Mediterranean palaeoenvironmental narratives produced by the literature, he specifically questioned the notion of an accentuated summer rain regime in the northern Mediterranean borderlands during the boreal insolation maximum.

To contribute to a better understanding of Holocene palaeohydrological changes in the Mediterranean area, this study presents a tentative synthesis of data recently collected in the central Mediterranean. This study forms part of a collaborative effort by LAMA ("Holocene changes in environment and climate, and histories of human societies in central Mediterranean as reflected by Lakes and Marines records") working group members to establish welldated high-resolution records for the Holocene in the central Mediterranean using both lacustrine and marine sediment archives. Study sites were strategically chosen along a north-south transect favoured by the geographical morphology of the Italian peninsula (Fig. 2). The investigations were 


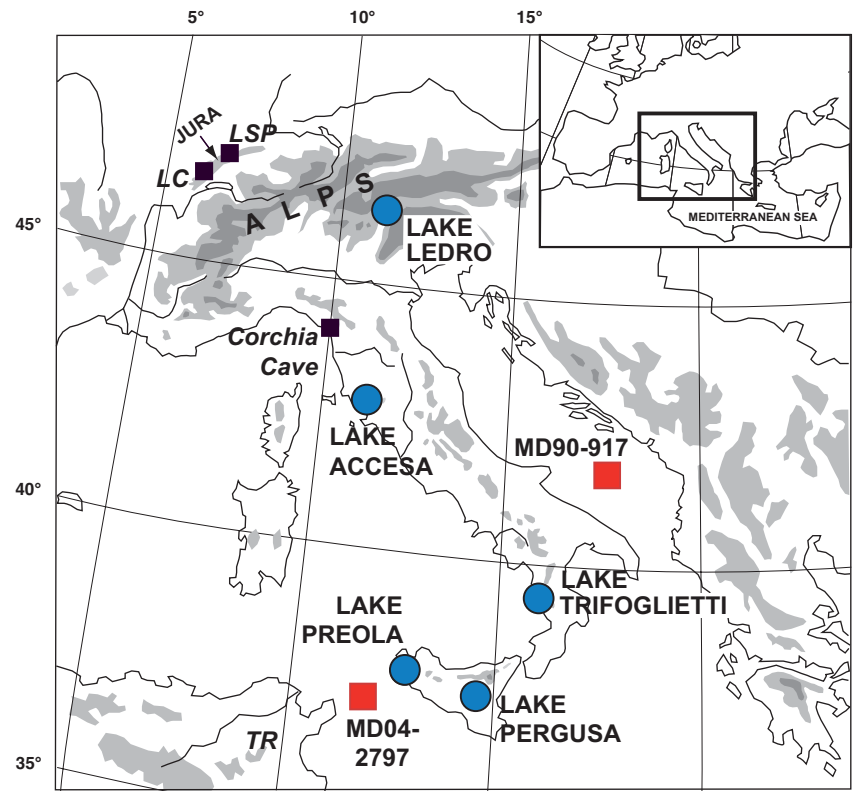

Fig. 2. Geographical location of marine and lacustrine study sites of the LAMA project in the central Mediterranean. LC: Lake Cerin; LSP: Lake Saint-Point.

developed using an integrated multi-proxy approach, based on a range of biotic and abiotic indicators. In this paper, after methodological preliminaries (Sect. 2), we first establish a synthesis of Holocene palaeohydrological changes as reflected by various proxies in the central Mediterranean. This synthesis considers both millennial and centennial scales and aims to identify regionally coherent patterns of changes in this region with north-south palaeohydrological contrasts (Sect. 3). Using a comparison with records established in adjacent and more distant areas from North Africa to Scandinavia, we then discuss the possible climatic significance of these palaeohydrological oscillations in terms of forcing factors and general patterns of atmospheric circulation (Sect. 4).

As a final note regarding scope, this synthesis paper does not have the ambition of carrying out an exhaustive review and interpretation of all the palaeohydrological data available in the literature for the Mediterranean Holocene. More reasonably, it aims at offering a synthesis of data collected in the central Mediterranean on the basis of a specific strategy, a multi-proxy approach, as far as possible homogeneous methods, and a comparison between strategically selected records from both neighbouring and more distant regions.

\section{Methodological preliminaries}

Some preliminary remarks will be helpful to better outline the methods and strategy behind the project LAMA. In addition to instrumental and historical data collected for the past recent centuries, various proxy data have been used to reconstruct and/or infer palaeohydrological changes which have punctuated the Holocene in the Mediterranean area, i.e. fluvial activity and alluvial sedimentation (e.g. Miramont et al., 2000; Giraudi, 2005a), lake-level fluctuations (e.g. Harrison and Digerfeldt, 1993; Giraudi, 1998, 2004; Magny et al., 2007), glacier variations (e.g. Orombelli and Mason, 1997; Giraudi 2005b), isotope studies from speleothems (e.g. Frisia et al., 2006; Drysdale et al., 2006; Zanchetta et al., 2007b), and lake sediments (e.g. Baroni et al., 2006; Zanchetta et al., 2007a; Roberts et al., 2008). Pollen data offer additional support for such reconstructions using (1) taxa considered as indicators of more or less humid conditions (e.g. de Beaulieu et al., 2005), (2) ratio between taxa to infer the establishment of present-day Mediterranean climatic conditions (Jalut et al., 2000 ) or the development of drier conditions less favourable to the expansion of the Mediterranean forests (e.g. Fletcher et al., 2013), and (3) quantitative approaches to estimate various climatic parameters (e.g. Davis et al., 2003; Kotthoff et al., 2008; Peyron et al., 2011).

Roberts et al. (2011) distinguished between primary and secondary climate proxies. While primary proxies provide records which can be unambiguously attributed to climatic forcing, secondary ones, such as pollen, geomorphological evidence of river incision, alluviation and fire regimes, produce records which may reflect either climatic changes or human activity, or a combination of the two, without excluding additional factors such as ecological dynamics. Thus, among primary proxies, lake and cave isotopes are assumed to offer one way to shed light on the causes of Holocene changes in the Mediterranean landscapes. The remarks by Roberts et al. (2011) call attention to the difficulties in disentangling natural and anthropogenic factors in the Mediterranean region where the human impact associated with the expansion of Neolithic societies appears to have come particularly early. However, as explained by Zanchetta et al. (2007b) and Develle et al. (2010), while being less sensitive to human impact than pollen or charcoal, isotop records offer a complex picture of past climatic conditions, given that they reflect changes in the isotopic composition of water resulting from complex interactions between the so-called source-, amount-, and temperature effects. In addition, apparent contradictions, on a regional scale, between isotope records and other palaeoclimatic data such as lake-level and glacial records (Baroni et al., 2006; Magny et al., 2007; Sarikaya et al., 2008; Roberts et al., 2008; Develle et al., 2010; Wagner et al., 2010; Milner et al., 2012) suggest an impact of seasonal conditions, the reconstruction of which also appears to be a central point for a better understanding of the Holocene trajectories of Mediterranean ecosystems and societies.

Consequently, the strategy and methods used for the present study may be summarised as follows:

- The study sites have been chosen along a north-south transect in the central Mediterranean to better capture possible influences of a latitudinal gradient. Thus, the project LAMA includes the sediment sequences from 
Lakes Ledro in Trentino, northern Italy, Accesa in Tuscany, central Italy, Trifoglietti in Calabria, southern Italy, Preola and Pergusa in Sicily, as well as the two marine cores MD90-917 in the southern Adriatic Sea and MD04-2797 in the Siculo-Tunisian strait (Fig. 2).

- The approach is based on an integrated multi-proxy analysis with the aim of reconstructing precipitation seasonality by independent but complementary means. Thus, regarding the palaeohydrological changes, which are the main topic of this paper, their reconstructions are mainly based on lake-level fluctuations and pollenbased quantitative estimates of climatic parameters, according to specific techniques described in detail and validated elsewhere (Overpeck et al., 1985; Guiot, 1990; Magny, 1992, 1998, 2004, 2006; Peyron et al., 2011). While the modern analogue technique (MAT) allows seasonal precipitation to be inferred from pollen data, the lake-level records established from variations in lithology and carbonate concretion assemblages are assumed to be mainly representative of summer moisture conditions (Magny, 1992; Magny et al., 2012c). However, the palaeohydrological signal given by the lakelevel records probably also includes an influence of the winter rainfall which may result in reinforced water volume in the lake basins before the summer dryness. This is supported by correlations between changes in lake level and NAO (North Atlantic Oscillation) indice over the last millennium (Magny et al., 2011c). Micro- or macro-charcoal and pollen data offer additional support for identifying drought periods favourable to increased frequency of fires as well as to forest declines or the expansion of dry-tolerant plants (Vannière et al., 2008, 2011; Desprat et al., 2013; Combourieu Nebout et al., 2009, 2013). In addition, in the case of Lake Ledro, sedimentological analyses of deep cores enabled us to establish a flood frequency record (Vannière et al., 2013).

- The approach is also based on the production of highresolution records to capture not only millennial trends of past environmental and climatic changes, but also centennial-scale events and possible abrupt changes.

- This is coupled with strong efforts to establish a robust chronology, which is a prerequisite for inter-regional correlations between records. Moreover, special attention has been paid to the identification of tephras, which support precise long-distance correlations between palaeoclimatic records (Zanchetta et al., 2012).

Before concluding the methodological preliminaries, it is worth noting the relative confusion which often characterises the terminology used for the subdivision of the Holocene in the Mediterranean area. Various terms are used from early/late to lower/upper Holocene. While the most frequent usage is a tripartite division of the Holocene (early, mid or middle, and late), the literature reveals that this distinction refers to various meanings both in terms of chronology and palaeoclimate/palaeoenvironment. Thus, "early Holocene" may correspond to the period's very beginning phase, or also include its maximum humidity phase, in contrast to "late Holocene" characterised by drier climate conditions as soon as they initiated, for instance ca. $7000-6000 \mathrm{cal} \mathrm{BP}$, or when they have already sufficiently developed, i.e. after ca. 5000$4000 \mathrm{cal}$ BP. The term "late Holocene" may also refer to a period characterised by an increasing human impact on the vegetation cover, in contrast to the early Holocene characterised by absent or limited human imprint. The two usages of term may converge chronologically but also show differences that depend on the region considered. Walker et al. (2012) have proposed formalising the tri-partition division of the Holocene by reference to the $8.2 \mathrm{ka}$ and the $4.2 \mathrm{ka}$ climatic events. Below, we will discuss how the data presented in this paper may help to test how well this new formal subdivision coincides (or not) with palaeoclimate records available for the central Mediterranean. So as to avoid any confusion, in this paper we will use the terms "early part", "middle/mid part" and "late part of the Holocene" to refer to time intervals different from those precisely defined by Walker et al. (2012). When used, the terms of "early Holocene", "middle/mid Holocene" and "late Holocene" systematically refer to the intervals $11700-8200,8200-4200$ and $4200-0$ cal BP defined by Walker et al. (2012).

\section{Contrasting patterns of Holocene palaeohydrological changes in the central Mediterranean: a tentative synthesis}

\subsection{Millennial trends}

We chose four lake-level records along a north-south transect from the Jura Mountains in west-central Europe (north of the Alps) to the south-central Mediterranean to exemplify the changes along a latitudinal gradient (Fig. 3). These records have been established from littoral cores using the same sedimentological approach, making the comparison easier. Lakes Ledro in northern Italy and Saint-Point in the Jura Mountains offer for comparison two additional palaeohydrological records established from deep cores: (1) that from Lake Ledro shows variations in flood frequency in general agreement with the pattern of lake-level fluctuations reconstructed from littoral cores in Lake Ledro (Magny et al., 2012b; Vannière et al., 2013), and (2) that from Lake Saint-Point presents palaeohydrological variations based on the estimation of detrital inputs into the lake using the ratio authigenic carbonate deposits/silicate input that reflects the hydrological activity of the lake inlets (Magny et al., 2013). In addition, Fig. 3 shows oxygen-isotope data and pollen- and sedimentinferred lake-level data from Lake Pergusa (Zanchetta et al., 2007a, b; Sadori and Narcisi, 2001; Sadori et al., 2008), as 


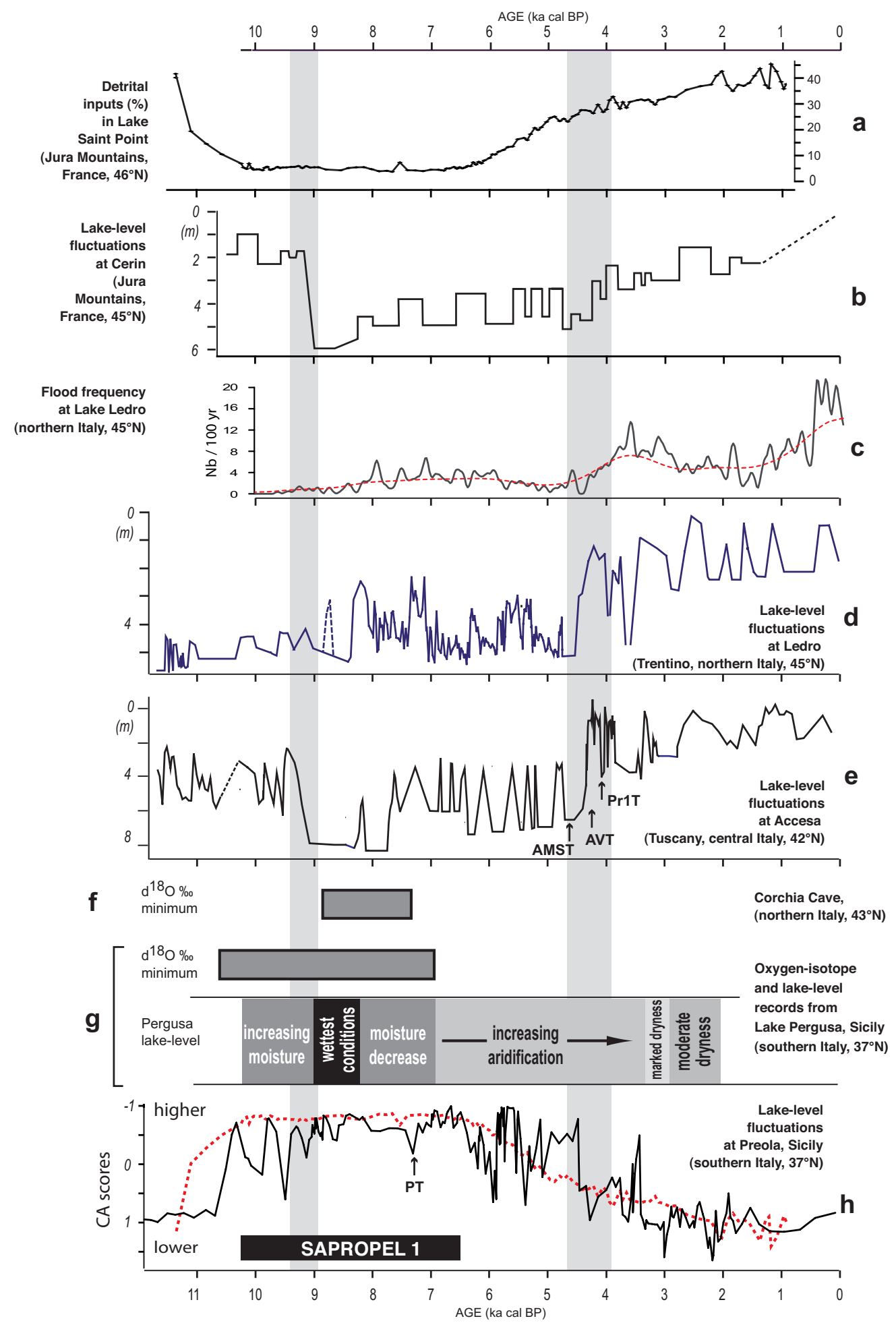

Fig. 3. Comparison between palaeohydrological records along a north-south transect from west-central Europe to the south-central Mediterranean, i.e. (a) Lake Saint-Point (Magny et al., 2013), (b) Lake Cerin (Magny et al., 2011a), (c and d)) Lake Ledro (Vannière et al., 2013; Magny et al., 2012b), (e) Lake Accesa (Magny et al., 2007), (f) Corchia Cave (Zanchetta et al., 2007b), (g) Lake Pergusa (Sadori and Narcisi, 2001; Zanchetta et al., 2007a; Sadori et al., 2008), and 8: Lake Preola (Magny et al., 2011b). The red curve in (h) is the Saint-Point palaeohydrological record after inversion (see panel a). The two vertical grey bands point out two major phases of palaeohydrological changes around 9000 and 4500 cal BP. Labels AMST, AVT and Pr1T in panel (e) correspond to the Agnano Mt Spina, Avellino and Pr1 tephras respectively, and PT in panel (h) to the Pantelleria tephra. 
well as oxygen-isotope data from Corchia Cave (Zanchetta et al., 2007b).

Considered as a whole, Fig. 3 gives clear, overall evidence of two opposing patterns in the central Mediterranean, with a middle part of the Holocene characterised by (1) a minimal wetness at Ledro and Accesa to the north, and (2) a maximal humidity at Lake Preola to the south. The direct comparison of the Lake Saint-Point and Preola records (Fig. 3h) gives a more striking illustration of the opposition between the Holocene palaeohydrological patterns that characterise two distinct zones, north and south of ca. $40^{\circ} \mathrm{N}$. Specific characteristics of the outlet area of Lake Ledro probably explain the generally low lake level prevailing from the early to the mid-Holocene (Magny et al., 2012b).

As illustrated by Fig. 4, such an opposition is fully supported by the differences between the patterns of fire activity reconstructed for the western Mediterranean by Vannière et al. (2011), with a maximum (minimum) fire frequency during the middle part of the Holocene to the north (south) of ca. $40^{\circ} \mathrm{N}$.

Regarding the chronology, the lake-level records presented in Fig. 3 lead to a definition of three successive phases within the Holocene as follows:

- Taken together, north of ca. $40^{\circ} \mathrm{N}$, the lake-level records of Accesa, Ledro and Cerin (Jura Mountains; Fig. 2) suggest a distinction of two humid periods before ca. $9000 \mathrm{cal} \mathrm{BP}$ and after ca. $4500 \mathrm{cal} \mathrm{BP}$. They were characterised by relatively wet summer conditions, and separated by a middle phase marked by drier summer conditions. The Ledro and the Accesa lake-level records show strong similarities with the Lake Cerin record north of the Alps in west-central Europe. This general palaeohydrological subdivision is close to that established by Moreno et al. (2011) at Lake Enol in northern Spain (ca. $\left.41^{\circ} \mathrm{N}\right)$.

- South of ca. $40^{\circ} \mathrm{N}$, the Preola lake-level record gives evidence of very dry summer conditions during the early part of the Holocene, with an absence of the lake until ca. $10300 \mathrm{cal} \mathrm{BP}$, more humid conditions between ca. 10300 and $4500 \mathrm{cal} \mathrm{BP}$, and an increase in summer dryness (in addition to a possible decrease in winter precipitation) after ca. $4500 \mathrm{cal} \mathrm{BP}$. In addition, wide lake-level fluctuations characterise two transition phases ca. $10300-9000$ and $6400-4500 \mathrm{cal}$ BP. This pattern is consistent (1) with oxygen-isotope data and lake-level changes inferred from sedimentological and pollen data at Lake Pergusa in Sicily (Fig. 3g; Zanchetta et al., 2007a, b; Sadori and Narcisi 2001; Sadori et al., 2008), and (2) with the maximum discharge of the Sele River in southern Italy (ca. $40^{\circ} \mathrm{N}$ ) between 10800 and $6900 \mathrm{cal} \mathrm{BP}$, reconstructed from a marine core in the Gulf of Salerno (Naimo et al., 2005).
Due to the absence of carbonate lake marl (metamorphic rocks in the catchment area), the sediment sequence of Lake Trifoglietti in Calabria did not allow a similar sedimentological method to reconstruct past Holocene lake-level changes in southern Italy. Nevertheless, variations in the water depth in the lake basin have been reconstructed using pollen data, i.e. a specific ratio between hygrophilous and terrestrial taxa (Joannin et al., 2013) (see Fig. 5). The results suggest relatively shallow water before $11000 \mathrm{cal} \mathrm{BP}$, a maximum water depth between 11000 and $6500 \mathrm{cal}$ BP (deep water between 11000 and $9000 \mathrm{cal} \mathrm{BP}$, intermediate water depth between 9000 and $6500 \mathrm{cal}$ BP), and a decreasing water depth after 6500 cal BP. While the Lake Trifoglietti water-depth record partly reflects the progressive infilling and the overgrowth of this small lake basin, the general pattern shown by Lake Trifoglietti appears to be in general agreement with a humidity maximum during the middle part of the Holocene in southern Italy (Naimo et al., 2005) and shows similarities with the Lake Dojran record in the Balkan region (Francke et al., 2013).

While some differences for the palaeohydrological transition chronology appear between the early and middle parts of the Holocene, all the records presented in Fig. 3 clearly show the key importance of the oscillation around $4500 \mathrm{cal} \mathrm{BP}$ in initiating relatively abrupt changes towards more humid (drier) summer conditions north (south) of ca. $40^{\circ} \mathrm{N}$. However, it is worth noting that the Preola record also shows that a trend towards lowering began as early as ca. $6500 \mathrm{cal} \mathrm{BP}$, in good agreement with the record of Lake Trifoglietti (see Fig. 5).

\subsection{Centennial-scale events}

A series of successive centennial-scale events punctuated the entire Holocene (Figs. 3 and 5). Regarding the north-central Mediterranean, the Ledro and Accesa lake-level records benefit from a robust chronology: that of Accesa is based on 43 radiocarbon dates and four tephra layers (Magny et al., 2007), and that of Ledro is based on 51 radiocarbon dates (Magny et al., 2012b). On both sites, the study of several littoral cores made it possible to well constrain the magnitude and chronology of the lake-level fluctuations.

Keeping in mind the age uncertainties inherent in radiocarbon dating, the centennial-scale events evidenced at Accesa and Ledro offer a consistent pattern not only on the regional scale of the north-central Mediterranean, but also in comparison to the west-central European record established north of the Alps (Magny, 2013). Thus, all together, these records display phases of increasing humidity around $10200,9300,8200,7300,6200,5700-5300,4800$, 4400-3800, 3300, 2700-2300, 1700, 1200 and $300 \mathrm{cal} \mathrm{BP.}$ Regarding the 11 500-11000 cal BP interval, differences appear with a more complex pattern of lake-level variations at Ledro and Accesa (a lowstand bracketed between highstand episodes; Figs. 3 and 5). Instead, the west-central 


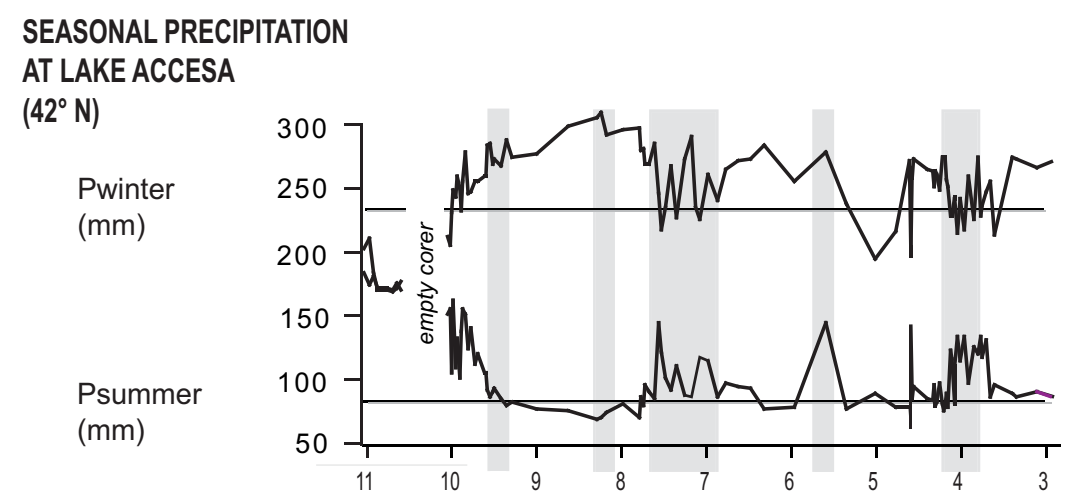

\section{SEASONAL PRECIPITATION \\ AT LAKE PERGUSA} $\left(37^{\circ} \mathrm{N}\right)$

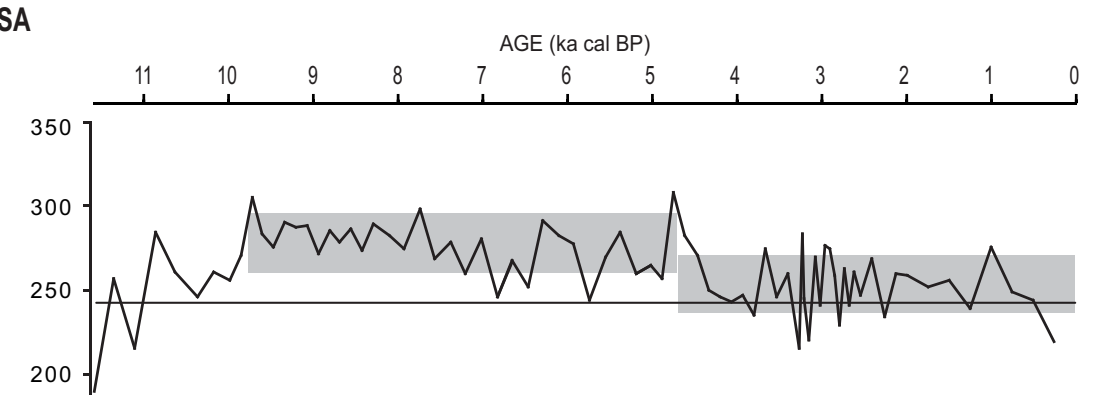

Psummer $(\mathrm{mm})$

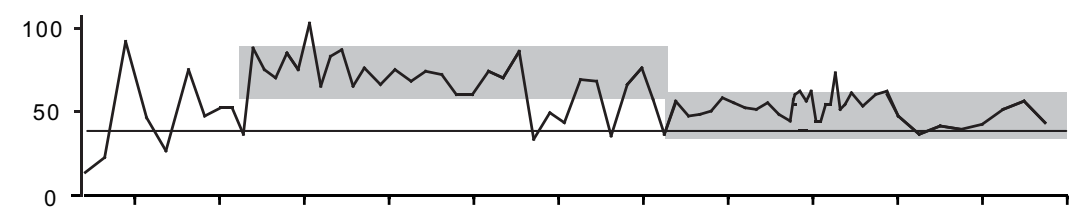

FIRE ACTIVITY

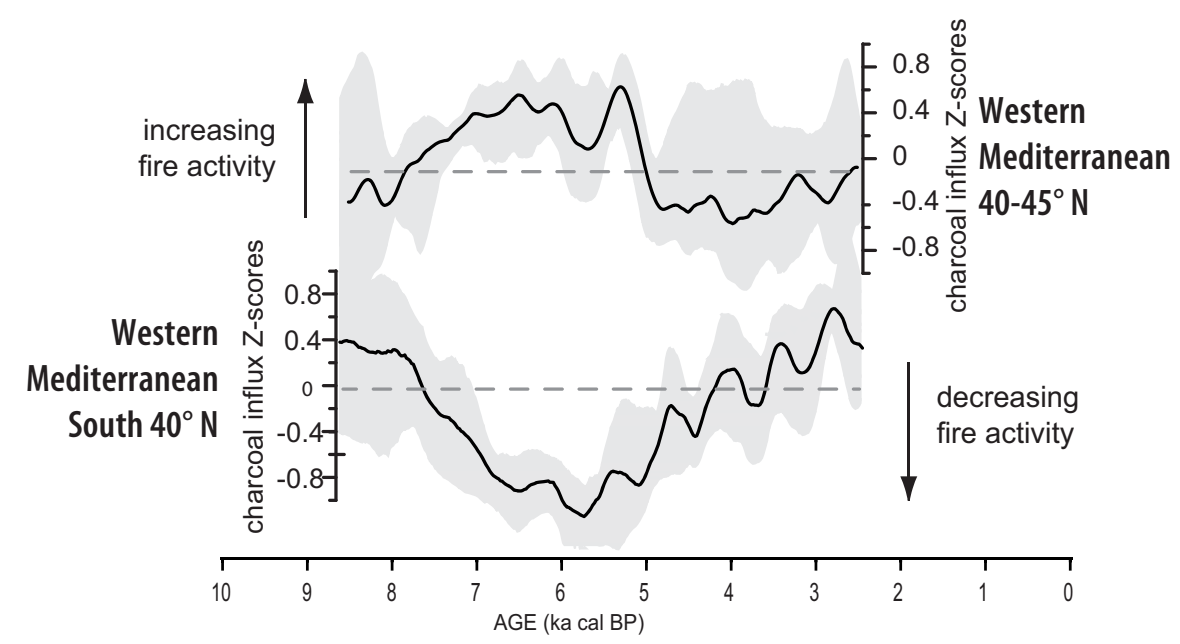

Fig. 4. (Top) Pollen-inferred estimates of seasonal precipitation at Lake Accesa (Peyron et al., 2011) and Lake Pergusa (Magny et al., 2012c; Peyron et al., 2013). (Bottom) Changes in fire regimes in north- and south-western Mediterranean (Vannière et al., 2011).

European lakes show a major lake-level highstand around 11 350-11 100 cal BP (Magny, 2013). In general, the phases of higher lake-level conditions in west-central Europe have been shown to coincide with cooling events in the North
Atlantic area (Bond et al., 2001; Magny, 1999, 2004, 2006, 2013).

In the south-central Mediterranean, it seems more difficult to define a series of centennial-scale events from Lake Preola. Although the two cores (LPA and LPBC) studied 


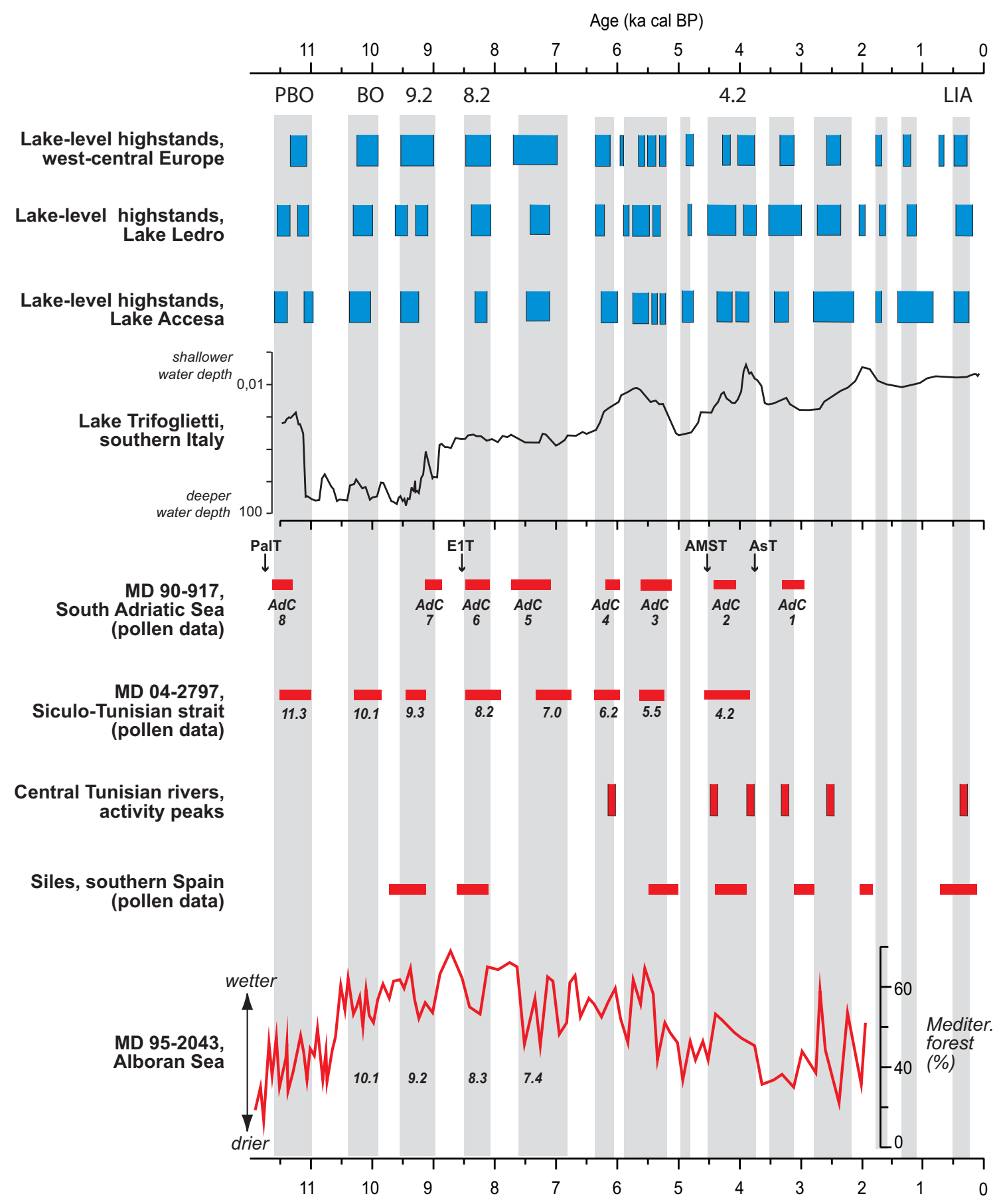

Fig. 5. Comparison between centennial-scale variations in humidity as reflected by lake-level, fluvial, and pollen records in west-central Europe and in the north- and south-western Mediterranean. To the north, wetter climatic conditions are marked by lake-level highstands (blue boxes) reconstructed for west-central Europe (Magny, 2004, 2006, 2013), Lake Ledro (Magny et al., 2012b), Lake Accesa (Magny et al., 2007), and Lake Trifoglietti (Joannin et al., 2013). To the south, dry phases (red boxes) are marked for activity peaks of Central Tunisian rivers (Ziehlhofer and Faust, 2008); pollen data at Siles (Carrión, 2002); and marine cores MD 90-917 (Combourieu Nebout et al., 2013), MD04-2797 (Desprat et al., 2013) and MD95-2043 (Fletcher et al., 2013). PBO: Preboreal oscillation; BO: Boreal oscillation; LIA: Little Ice Age. For the MD90-917 record, the labels PalT, E1T, AMST and AsT correspond to the Palinuro, E1, Agnano-Monte Spina and Astroni tephras, respectively. 
at Preola display a general agreement for the millennial trends and the abrupt fall in lake level around $4500 \mathrm{cal} \mathrm{BP}$, they show discrepancies in the details for the period after 4500 cal BP due to possible influence of overgrowth process (Magny et al., 2011b). Regarding the period before $4500 \mathrm{cal} \mathrm{BP}$, the littoral core LPA gives evidence of major lowstands at around $10100,9500,8500-8200,7500,6400$ 6000 , and 5500-5000 cal BP. Core LPBC taken in the centre of the lake basin gives nearly similar results except for the lowstand dated to $8900-8600$ instead of $8500-8200$ cal BP in core LPA (Magny et al., 2011b).

To enlarge the documentation for the south-central Mediterranean, Fig. 5 presents pollen data obtained from marine core MD04-2797 in the Siculo-Tunisian strait (Desprat et al., 2013). In close agreement with the palaeohydrological pattern given by the Preola lake-level record, the general background is characterised first by a dominance of steppic taxa (dry climatic conditions), followed by an extension of temperate trees and shrubs between 10100 and $6600 \mathrm{cal} \mathrm{BP}$ (wetter conditions), and finally by a development of Mediterranean plants from ca. $6600 \mathrm{cal}$ BP onwards (increasing dryness). Superimposed on this general background supported by mineralogical and geochemical analyses of core MD042797 (Bout-Roumazeilles et al., 2013), recurrent episodes of Mediterranean forest reduction or changes in the herbaceous layer such as an increase in semi-desert plants (indicator of dryness) and/or a decrease in Cyperaceae (indicator of humidity), which are synchronous with alkenone-inferred cooling phases, give evidence of successive dry centennialscale events marked by cooler and drier climatic conditions at ca. $11300,10100,9300,8200,7000,6200,5500$ and 4200 cal BP (Fig. 5). This series of centennial-scale events finds an equivalent in episodes of forest declines reconstructed from core MD90-917 in the southern Adriatic Sea (Combourieu Nebout et al., 2013).

This suggests that, in response to centennial-scale cooling events, drier climatic conditions developed in the southcentral Mediterranean, while an opposite pattern prevailed in the north-central Mediterranean with wetter climatic conditions. As illustrated in Fig. 5, the water-depth record of Trifoglietti $\left(\mathrm{ca} .39^{\circ} \mathrm{N}\right.$ ) supports these conclusions with phases of shallower water around 5500 and $4000 \mathrm{cal} \mathrm{BP}$. As discussed by Joannin et al. (2013), if we take into account the radiocarbon age uncertainty (standard deviation), the lowering which developed between 2500 and 1800 cal BP may be equivalent to the well-known phase identified around 2700-2500 cal BP at the Subboreal-Subatlantic transition (van Geel et al., 1996). Another relevant interpretation, if we consider the relatively northern latitudinal location of Lake Trifoglietti at more than $39^{\circ} \mathrm{N}$, may be to infer a possible slight migration south to $40^{\circ} \mathrm{N}$ of the boundary between the north- and the south-central Mediterranean sectors characterised by contrasting palaeohydrological patterns.

Farther in the western Mediterranean, but still south of $40^{\circ} \mathrm{N}$, pollen data from sites of Siles in southeastern Spain $\left(\right.$ ca. $38^{\circ} \mathrm{N}$ ) reveal successive desiccation episodes ca. 9300, $8400,5200,4100,2900,1900,600-300 \mathrm{cal} \mathrm{BP}$, in general agreement with data obtained at similar latitudes in the southcentral Mediterranean except for phases around 2900 and 1900 cal BP (Carrión, 2002). A pollen record from marine core MD95-2043 in the Alboran Sea, at the extremity of the western Mediterranean around $36^{\circ} \mathrm{N}$ (Fletcher et al., 2013) displays a series of successive episodes of forest decline as shown by Fig. 5. It is noteworthy that no dry event appears around $4000 \mathrm{cal} \mathrm{BP}$ in the MD95-2043 pollen record, in contrast to core MD04-2797, but the temporal resolution of the record around this time interval is relatively poor. Using a smoothed curve of Mediterranean forest taxa, Fletcher et al. (2013) proposed to synchronise the forest decline episodes with phases of mid-European lake-level highstands during the interval $10500-7000 \mathrm{cal} \mathrm{BP}$, and to the contrary, with phases of mid-European lake-level lowstands for the interval 7000-1000 cal BP. However, Magny (2013) has shown how the mid-European record of lake-level highstands is more representative of past palaeohydrological changes in the European mid-latitudes and should preferably be used as being reference for the lake-level changes in westcentral Europe, whereas a reference limited to lowstands may be a source of confusion and mistakes. Moreover, as discussed in detail below (see Sect. 4.3), the comparison of the MD95-2043 record with data from adjacent areas (Carrión, 2002; Combourieu Nebout et al., 2009) suggests a possibly more complex interpretation, likely due to a fluctuating limit between the southern and the northern palaeohydrological Mediterranean sectors.

Though human impact may have provoked vegetation change in the late Holocene, the two successive peaks of Mediterranean tree taxa, dated to ca. 2700 and 2300 cal BP in the MD95-2043 pollen record, reflect wetter climatic conditions (Fletcher et al., 2013), in good agreement with the Siles record in which a more humid interval developed between two desiccation phases dated to ca. 2900 and 1900 cal BP (Carrión, 2002). This suggests a migration south to $40^{\circ} \mathrm{N}$ of the boundary between the opposing north and south Mediterranean hydrological sectors at the edge of the western Mediterranean around $2500 \mathrm{cal}$ BP. The same interpretation does not appear to be pertinent to high values of Mediterranean tree taxa around 4400-3800 cal BP since the hypothesis of a migration of the boundary between northern and southern Mediterranean hydrological sectors southwards to ca. $36^{\circ} \mathrm{N}$ is inconsistent with the dry conditions reconstructed at Siles (ca. $38^{\circ} \mathrm{N}$ ) for the same period. This suggests that new records with higher temporal resolution are needed for a better understanding of climatic conditions in this region around 4400-3800 cal BP. Later, during the Little Ice Age (LIA), this boundary may have been located north of ca. $38^{\circ} \mathrm{N}$ in southern Spain as suggested by dry conditions at Siles (Carrión, 2002). 


\subsection{Contrasting patterns of precipitation seasonality between the north- and the south-central Mediterranean}

As discussed in Sect. 3.1., lake-level and fire event data provide robust and consistent records to shed light on the summer moisture availability. When not determined by anthropogenic activities, fire frequency depends on the duration and intensity of the dry season (Pausas, 2004; Vannière et al., 2011), while the main proxies used for lake-level reconstruction in this study are characteristic of the warm season (Magny, 2006). The fire records shown in Fig. 4 confirm the contrasting patterns between the north- and the southwestern Mediterranean for the mid-Holocene (Vannière et al., 2011), with higher frequency of fires to the north (summer dryness) and less frequent fires to the south (more humid summers). The fire record of Lake Eski Acigöl in central Turkey at ca. $38^{\circ} \mathrm{N}$ (Turner et al., 2008) fully supports this general pattern with minimum fire frequency between 9000 and $7000 \mathrm{cal} \mathrm{BP}$.

Quantitative estimates inferred from pollen data offer useful complementary data (indirect proxy following Roberts et al., 2011) to reconstruct the precipitation seasonality in the central Mediterranean. Figure 4 presents quantitative estimates of winter and summer precipitation for the Holocene in the north- and the south-central Mediterranean using MAT from pollen data of Lakes Accesa (Peyron et al., 2011) and Pergusa (Sadori and Narcisi, 2001; Magny et al., 2012c). First, the values obtained for the summer precipitation show general trends in good agreement with the lake-level records, i.e. they support the assumption that the south-central Mediterranean underwent a phase of maximum summer wetness between ca. 10500 and $4500 \mathrm{cal} \mathrm{BP}$, while the north-central Mediterranean was marked by a maximal summer dryness between ca. 9500 and 4500 cal BP. Regarding the winter season, pollen-inferred estimates suggest that both the northern and the southern areas underwent a precipitation maximum during the middle part of the Holocene, and more particularly during the interval $10000 / 9500-7500 / 7000 \mathrm{cal}$ BP, i.e. broadly during the deposition of Sapropel 1 (Mercone et al., 2000). The quantitative estimates show that the summer precipitation was more affected by the climate drying than the annual and the winter precipitation. Thus, the mid- to late Holocene transition corresponds to a mean lowering by ca. $10-8 \%$ for annual and winter precipitation whereas the decrease in wetness reaches more than $30 \%$ in summer. This progressively leads to a stronger seasonal contrast in precipitation, typical of the current Mediterranean climate of the région (Magny et al., 2012c). Comparisons with climatic data obtained in northern Greece in the Boras mountains (Lawson et al., 2005) and from Tenaghi Philippon in northern Greece (Peyron et al., 2011) as well as marine cores in the Aegean Sea suggest that the climate trends and the north-south contrasts observed in the central Mediterranean show strong similarities with those identified in the Balkans (Peyron et al., 2013).

According to Magny et al. (2007, 2011b, 2012c), such a combination of differences and similarities between the north- and the south-central Mediterranean during the middle part of the Holocene, depending on the season under consideration, may explain the apparent conflict between palaeoclimatic records, depending on the proxy used for the reconstructions. For example, the stable isotope record from a speleothem of Corchia Cave in north-central Italy reveals enhanced rainfall between ca. 8900 and $7300 \mathrm{cal} \mathrm{BP}$, which probably reflects an increase in the winter precipitation originating from the North Atlantic Ocean (Zanchetta et al., 2007b). All together, these data also support the discussion by Tzedakis (2007) who (1) questioned the notion of an accentuated summer rain regime in the northern Mediterranean borderlands contributing to a freshening of the Mediterranean Sea during the boreal insolation maxima, and (2) hypothesised a summer aridity at that time. Such a contrasting seasonality in the Mediterranean during the Holocene interglacial has recently been reconstructed for the Eemian interglacial by Milner et al. (2012). To sum up, in addition to the monsoon-related enhanced Nile discharge (Revel et al., 2010), the deposition of Sapropel 1 has been favoured by an increase (1) in winter precipitation in the northern Mediterranean borderlands, and (2) in winter and summer precipitation in the southern Mediterranean area.

Moreover, reference to contrasting patterns of precipitation seasonality reconstructed for the central Mediterranean has shed new light on the Holocene development and vegetation trajectories in the western Mediterranean. Palaeoecologists have proposed various hypotheses about the possible factors driving the increase in broadleaf evergreen vegetation during the Holocene, i.e. wildfires (e.g. Carcaillet et al., 1997), human impact (e.g. Lang, 1994), or summer drought (Jalut et al., 2000). As discussed by Colombaroli et al. (2009) for the central Mediterranean, analyses suggest that the expansion of Quercus ilex developed as a response to contrasting hydrological conditions in the north. Quercus ilex expanded as early as $8500 \mathrm{cal} \mathrm{BP}$ at Accesa and replaced deciduous forests when the climatic conditions became drier. This is well illustrated by synchronous $Q$. ilex peaks and lake-level lowstands at Accesa (Magny et al., 2007). In the south, it began to expand only at $7000 \mathrm{cal} \mathrm{BP}$ at Preola (Tinner et al., 2009; Calò et al., 2012) and Biviere di Gela in low-elevated coastal areas of southern Sicily, but as early as 9000 cal BP at the higher elevation site of Pergusa (Sadori and Narcisi, 2001), where it replaced maquis or steppe vegetation when climatic conditions became moister. In addition, precipitation seasonality may help to explain synchronous expansion of taxa with apparent opposite requirements in humidity. Thus, the contemporaneous maxima of Abies and $Q$. ilex at Accesa in the mid-Holocene may be explained by a combination of maximal (minimal) winter (summer) humidity. 


\subsection{Climato- and tephro-stratigraphies}

Several lacustrine and marine sediment sequences studied within the LAMA project have revealed tephra layers (Figs. 3 and 5) which offer the opportunity to better constrain correlations between palaeoclimatic/palaeohydrological- and tephro-stratigraphies. Inter-regional correlations between records on a centennial scale are often limited due to chronological uncertainties linked to inaccuracies inherent in the radiocarbon dating (calibration time-window, marine reservoir effect) (Zanchetta et al., 2011). In this general context, tephra layers offer key time-marker horizons to physically correlate different records. From this point of view, the sediment sequence of Lake Accesa and that of core MD90-917 provide important contributions to establishing possible correlations between climato- and tephro-stratigraphies as set out below.

Three tephra layers have been identified in the Holocene sediment sequence of core AC03-04 of Lake Accesa (Magny et al., 2007, 2009; Fig. 3):

- The Agnano-Monte Spina (AMST) and the Avellino (AVT) tephras, from the Phlegrean Fields and from the Vesuvius respectively, offer key horizons for the beginning of the Neoglacial in the central Mediterranean around $4500-3800 \mathrm{cal}$ BP. As summarised by Zanchetta et al. (2012), major environmental changes, such as rise in lake level at Accesa and glacier advance in the Gran Sasso Massif (central Italy), occurred just after the deposition of the AMST and predate that of the AVT. Moreover, a second distinct layer (Pr1) corresponding to the end phase of the Avellino event (interplinian events AP2-AP4; Wulf et al., 2004; Rolandi et al., 1998) was deposited during a short-lived lowstand between the two successive high lake-level phases which characterise the starting Neoglacial at Lake Accesa (Magny et al., 2007, 2009).

At Lake Preola, core LPBC gives evidence of a tephra layer dated ca. $7300 \mathrm{cal}$ BP from the age-depth model (Magny et al., 2011b). It corresponds to an eruption from Pantelleria Island and was deposited during a maximal dryness phase marked by a lake-level lowering and an accumulation of eolian sand (Fig. 3).

In core MD90-917, Siani et al. (2010, 2013) have identified several tephras of interest for correlation between tephro- and climato-stratigraphies (Fig. 5).

- The Palinuro tephra from Seamount Palinuro was deposited just at the Younger Dryas/Holocene transition (Siani et al., 2006). It is dated $9990 \pm 90{ }^{14} \mathrm{C}$ yr BP (i.e. ca. $11460 \mathrm{cal} \mathrm{BP}$ ).

- The E1 tephra (Paterne et al., 1998; Fontugne et al., 1989) is correlated with the Gabellotto-Fiumebianco eruption from the Lipari Islands. It marks the top of the interval S1a, just before the interruption of Sapropel 1 deposition that corresponds to the $8.2 \mathrm{ka}$ event in the Mediterranean.

- In agreement with the terrestrial records from Central Italy (Zanchetta et al., 2012), the AMST predates the beginning of a cooling event that developed around 43003800 cal BP, while the Astroni tephra from the Phlegrean Fields marks its final part.

Further to the east, in the Balkan region, the Mercato tephra constrains the age of the 8.2 cooling event (Aufgebauer et al., 2012; Vogel et al., 2010; Wagner et al., 2009), while the FL tephra constrains the age of a dry and cold period around 4000 cal yr BP at Lake Ohrid (Wagner et al., 2009, 2012; Vogel et al., 2010), and the AD472/512 tephra constrains the onset of the MWP at lakes Ohrid and Prespa (Aufgebauer et al., 2012; Wagner et al., 2009, 2012; Vogel et al., 2010).

\section{Forcing factors and past atmospheric circulation patterns}

\subsection{Preliminary remarks}

As noted by Tzedakis (2007), the wealth of palaeoenvironmental/palaeoclimatic data collected from the Mediterranean area has led to increasingly complex (sometimes conflicting) scenarios which reflect the possible complexity of climatic mechanisms that have operated in a region at the interface between high- and low-latitude influences as well as between western (North Atlantic Ocean) and eastern (Eurasia, Indian Ocean) interactions.

Given that the Mediterranean region is located at the transition between the temperate and tropical zones, it is influenced by the dynamics of both the tropical circulation cells and the mid-latitude westerlies. Today, the mechanisms which control the marked seasonal precipitation contrasts in the Mediterranean area offer a possible modern analogue for palaeoclimatic studies (Tzedakis et al., 2009). While the northward migration of the Intertropical Convergence Zone (ITCZ) across the Equator determines the development of the rainy season in the Tropics (monsoonal systems) in the boreal summer, it brings the Mediterranean under the influence of the subtropical anticyclone belt and, as a result, widespread aridity. In contrast, its southward migration in winter allows the influences of mid-latitude westerlies to penetrate the Mediterranean basin. This also results in a north-south humidity gradient in the Mediterranean with the dry summer season lasting less (more) than five months north (south) of ca. $40^{\circ} \mathrm{N}$ (Quézel and Medail, 2003).

Geographical characteristics may reinforce this general complexity. The Mediterranean Basin is composed of two distinct basins separated by the Italian Peninsula and Sicily, with a western basin located at more northerly latitudes between ca. $45^{\circ}$ and $35^{\circ} \mathrm{N}$ and closer to the influences of the North Atlantic Ocean, and an eastern basin located at 
more southerly latitudes between ca. $40^{\circ}$ and $30^{\circ} \mathrm{N}$, farther away from the North Atlantic Ocean but more exposed to influences from continental Europe such as the Siberian High (Rohling et al., 2002; Pross et al., 2009), or to possible interactions with the African and south Asian monsoon (Staubwasser and Weiss, 2006).

The Mediterranean area is also affected by atmospheric circulation patterns responsible for regionally contrasting hydrological conditions. Many studies have demonstrated that the North Atlantic Oscillation (NAO) coupled with the Arctic Oscillation (AO) is the most prominent mode of variability of the North Atlantic and Mediterranean region winter climate (e.g. Hurrell, 1995; Wanner et al., 2001; Xoplaki, 2002). In winter, the atmospheric circulation in this area is characterised by a strong north-south pressure contrast (expressed by the NAO index) between the Icelandic low and the Azores high. This pressure gradient drives the strength of the westerly flow bringing more (positive NAO) or less (negative NAO) mild moist air to north-western Europe. Regarding the Mediterranean area, the NAO provokes marked regional hydrological contrasts. Thus, under positive NAO, the Mediterranean northern borderlands experience dry conditions when the southern Mediterranean benefits from increasing precipitation like in north-western Europe (see below) (Marshall et al., 2001; Dünkeloh and Jacobeit, 2003). Opposite contrasts develop under negative NAO conditions. It is worth noting that the boundary between the two opposite hydrological sectors of the Mediterranean may be affected by latitudinal fluctuations. Thus, in recent times, depending on the reference period considered, northern Morocco and the region of the Gibraltar Strait to the west, and southern Turkey to the east, may or may not both be included in the northern Mediterranean sector (Marshall et al., 2001; Lamy et al., 2006; Lionello et al., 2006). As noted by Dünkeloh and Jacobeit (2003), the so-called Mediterranean Oscillation (MO), associated with similar hydrological contrasts between north-western and south-eastern Mediterranean sectors, must not be seen as independent large-scale circulation modes since they correlate significantly with the Northern Hemisphere modes of the AO/NAO, and may be considered as the Mediterranean expression of the NAO in terms of precipitation variability.

In addition to the NAO, various (secondary) circulation patterns acting over the Mediterranean area (such as the East Atlantic-West Russian and North Sea-Caspian patterns) have been identified by means of recent time series of meteorological data (e.g. Xoplaki, 2002). Interestingly, Dünkeloh and Jacobeit (2003) have established maps of precipitation anomalies associated in the Mediterranean Basin to main circulation patterns distinguished for the period 1948-1998. These maps reveal the complex hydrological patchworks which may result on regional scale from these different atmospheric circulation patterns. This may be a source of additional difficulties in identifying regionally coherent patterns from palaeoclimatic data.
A further complexity originates from changes which affect boundary conditions during the Holocene interglacial. This includes orbitally-driven changes in insolation and its seasonal as well as interhemispheric distribution (Berger, 1978; Berger and Loutre, 1991; Wanner et al., 2011). The insolation maximum coincided with a northward migration of ITCZ and a reinforcement of the African and Indian monsoons (Tzedakis et al., 2009; Revel et al., 2010; Fleitmann et al., 2007), as well as a prevailing positive mode of the NAO (Gladstone et al., 2005; Davis and Brewer, 2009; Dyck et al., 2010). The deglaciation is also responsible for substantial changes in the boundary conditions with the successive disappearance of the Fennoscandian and Laurentide ice sheets around 9500-9000 and 7500-7000 cal BP respectively (Lundqvist and Saarnisto, 1995; Renssen et al., 2009; Carlson et al., 2008). At a centennial scale, rapid deglaciation freshwater outbursts were still associated during the early Holocene with successive abrupt cold events in the North Atlantic area, such as the well-known 8.2 ka event (Alley et al., 1997).

Last (but not least), a final difficulty may be seen in the wide variety of proxies used for the establishment of palaeoenvironmental/palaeoclimatic records from both marine and terrestrial cores in the Mediterranean basin. This leads to a plethora of palaeodata which theoretically may favour the reconstruction of various (seasonal) aspects of past changes in environmental/climatic conditions. But this also may be responsible for difficulties in cross-correlations between records due to differences in the signal recorded by proxies (or in their sensitivity threshold), resulting in possible leads and lags between proxies and apparently in no synchronous changes in the records.

Taking into account the main features and the complexity which characterise the Holocene in the Mediterranean area, Figs. 6, 7, 8 and 9 present a comparison of selected records to place the Mediterranean in a more general context and help to identify possible key factors, on both millennial and centennial scales, responsible for hydrological changes in this area over the last $11700 \mathrm{yr}$.

\subsection{Millennial trends}

To place the palaeohydrological records from the Mediterranean in a large-scale context, they may be compared with selected records from northern Africa to northern Europe, as illustrated by Figs. 6 and 7. In Fig. 6, the lake-level records from Preola, Accesa and Cerin have been reconstructed by Magny et al. (2007, 2011a, b). The record established at Jostedalsbreen by Nesje et al. (2000) displays variations in precipitation in western Norway, while the annual precipitation record at Lake Svanåvatnet (northern Norway) has been produced by Bjune and Birks (2008) using pollen-inferred quantitative estimates. Finally, the upper panel of Fig. 6 shows records indicating general climatic conditions in the Finnish Lapland as reflected by (1) the altitude of the highest 


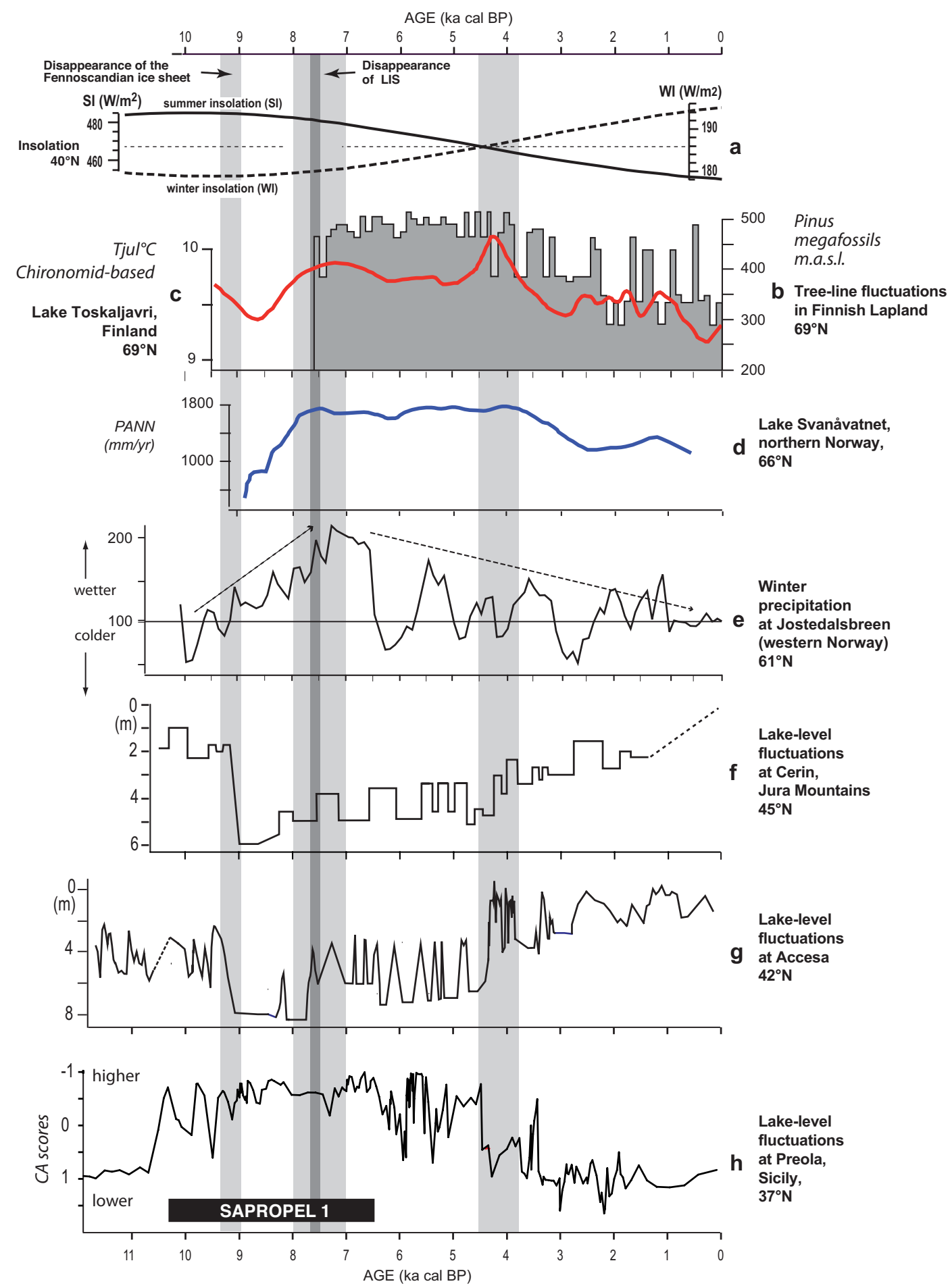

Fig. 6. Comparison between palaeohydrological and palaeoclimatic records along a north-south transect from Scandinavia to south-central Mediterranean. (a) Curve of summer and winter insolation at $40^{\circ} \mathrm{N}$ (Berger and Loutre, 1991), (b) tree-line altitude in Finnish Lapland and (c) chironomid-based summer temperature record from Lake Toskaljavri in Finland (Seppä et al., 2008), (d) annual precipitation at Lake Svanåvatnet in northern Norway (Bjune and Birks, 2008), (e) winter precipitation at Jostedalsbreen in western Norway (Nesje et al., 2000), (f) lake-level records at Cerin in west-central Europe (Magny et al., 2011a), (g) at Lake Accesa in north-central Mediterranean (Magny et al., 2007), and (h) at Lake Preola in south-central Mediterranean (Magny et al., 2011b). Vertical grey bands indicate (i) the periods of disappearance of the Fennoscandian and Laurentide ice sheets (LIS) according to Renssen et al. (2009), Jansson and Kleman (2004) and Törnqvist and Hijma (2012) with an episode of increasing sea-level rise around 7600 cal BP (Carlson et al., 2008), and (ii) a period of major climatic/palaeohydrological change around 4500-4000 cal BP. 


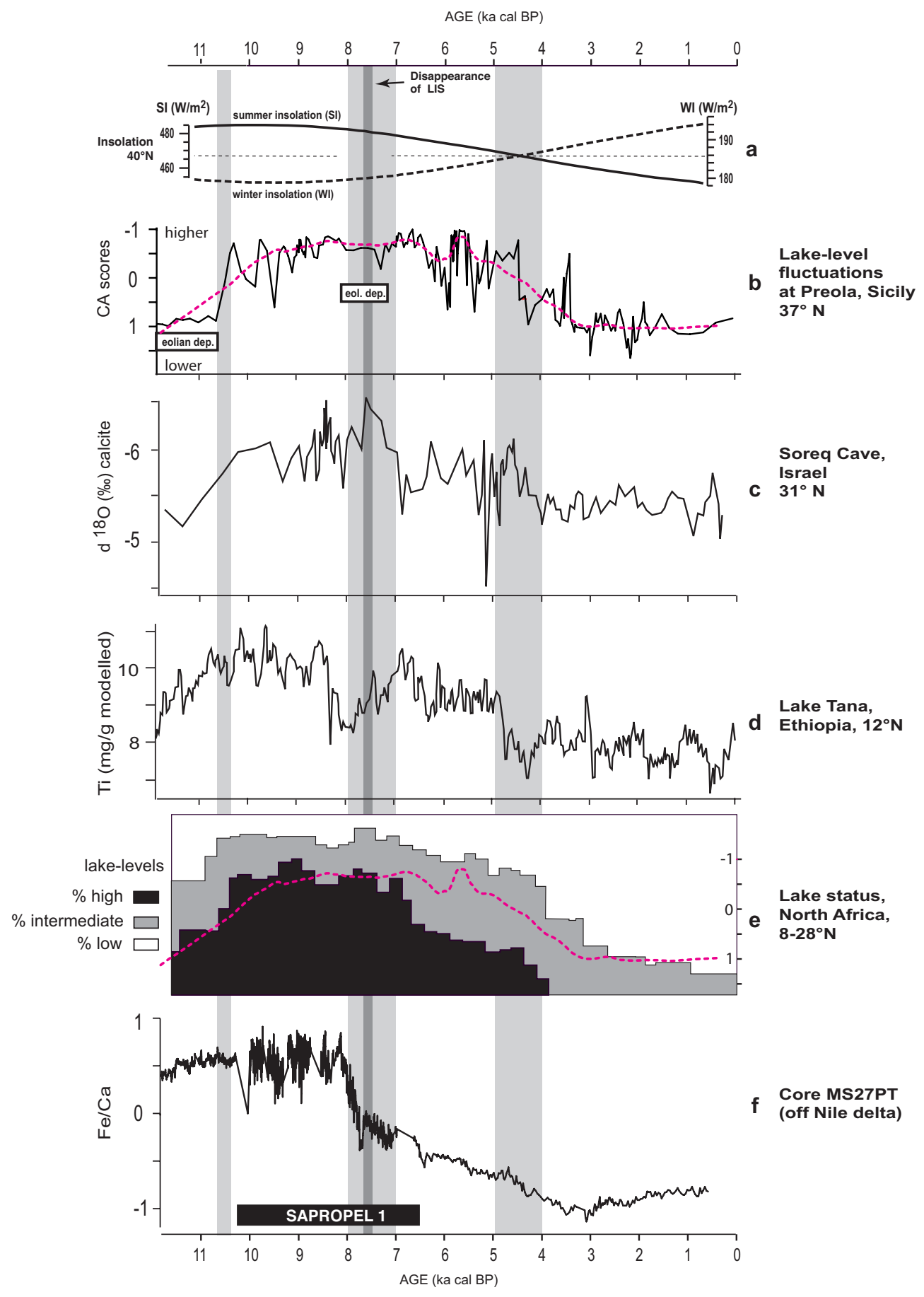

Fig. 7. Comparison between palaeoclimatic and palaeohydrological records from the Mediterranean area and North Africa, i.e. (a) curve of summer and winter insolation at $40^{\circ} \mathrm{N}$ (Berger and Loutre, 1991), (b) lake-level record from Lake Preola in south-central Mediterranean (Magny et al., 2011b; smoothed curve in red), (c) oxygen-isotope record from Soreq Cave (Bar-Matthews et al., 1998), (d) Ti record from Lake Tana in Ethiopia (Marshall et al., 2011), (e) lake-level status of North African lakes between $8^{\circ}$ and $28^{\circ} \mathrm{N}$ (Hoelzmann et al., 1998 ; Gasse and Roberts, 2004), and (f) Fe/Ca record from core MS27PT off the Nile delta (Revel et al., 2010). The red dotted curve in (e) is the smoothed Preola lake-level record (see panel b). Vertical grey bands indicate (i) the periods of disappearance of the Fennoscandian and Laurentide ice sheets according to Renssen et al. (2009), Jansson and Kleman (2004) and Törnqvist and Hijma (2012) with an episode of increasing sea-level rise around $7600 \mathrm{cal} \mathrm{BP}$ (Carlson et al., 2008), and (ii) periods of major climate change around 10500 and $5000-$ 4000 cal BP. 
pine megafossil in 200-yr intervals and (2) a chironomidinferred temperature record ( Seppä et al., 2008). In Fig. 7, the Fe record from core MS27PT off the Nile Delta has been established by Revel et al. (2010) and reflects the sediment input from the Blue Nile resulting from the African monsoon. The lake-level pattern of the northern part of Africa has been established using various data from the region between $8^{\circ}$ and $28^{\circ} \mathrm{N}$ (Hoelzmann et al., 1998; Gasse and Roberts, 2004). The Ti record from Lake Tana in Ethiopia has been established by Marshall et al. (2011) to infer variations in effective precipitation in the area of the source of the Blue Nile. The oxygen-isotope record from Soreq Cave gives evidence of variations in the wetness in the south-eastern Mediterranean (Bar-Matthews et al., 1998). Finally, the Preola lakelevel record has been added in the upper panel of Fig. 7 to facilitate the comparison between the palaeohydrological records from the south-central and eastern Mediterranean.

Taken together, Figs. 6 and 7 reveal several mean features as follows.

- The palaeohydrological records show (1) a general increase in humidity during the middle part of the Holocene in tropical North Africa, in the south-central Mediterranean and in Norway, and (2), in contrast, drier conditions (lake-level minimum) in the north-central Mediterranean and in west-central Europe.

- Like the lake-level records from Lakes Tanganyika, Turkana and Chew Bahir in equatorial Africa (Marshall et al., 2011; Garcin et al., 2012; Foerster et al., 2012), the MS27PT record off the Nile Delta shows a maximum of humidity (monsoon rainfall) as early as the beginning of the Holocene, which prolongs a strong Late Glacial Bølling-Allerød increase interrupted by the dry Younger Dryas event (Revel et al., 2010). In contrast, the other palaeohydrological records presented in Figs. 6 and 7 give evidence of increasing time lags of the hydrological signal towards northern latitudes, with a maximum (or a minimum in the north-central Mediterranean and in west-central Europe) of humidity starting around $10500 \mathrm{cal}$ BP in North African lakes (in agreement with Lézine et al., 2011), at Lake Preola and at Soreq Cave, around 9000 cal BP at Lakes Accesa and Cerin, and finally at ca. $7500 \mathrm{cal}$ BP at Jostedalsbreen and Stanåvatnet in northern Norway. This suggests a shortening of the duration of the Holocene climatic optimum from the southern to the northern latitudes.

- Regarding the mid- to late Holocene, the palaeohydrological records in Figs. 6 and 7 highlight two phases of major changes around 8000-7000 cal BP and 45004000 cal BP.

The data presented in Figs. 6 and 7 suggest that palaeohydrological changes reflect a combination of two major forcing factors, i.e. orbitally-driven insolation and deglaciation:
- According to Davis and Brewer (2009), the maximal strength of the African monsoon shows a close relationship with the peak of summer insolation near the Equator in the North African tropics. This is in agreement with the early maximum of sediment input (i.e. Blue Nile discharge) observed off the Nile Delta by Revel et al. (2010) and the early Holocene maximum of humidity shown by the lake-level records from equatorial Africa (Marshall et al., 2011; Garcin et al., 2012; Foerster et al., 2012).

- On the basis of western- and central Mediterranean records it has been suggested that dry conditions during the early Holocene in the (southern) Mediterranean may have resulted from the strong Hadley cell activity in response to the orbitally-driven summer insolation maximum (Tinner et al., 2009). This is corroborated by our new compilation, which shows that dry conditions prevailed south of ca. $40^{\circ} \mathrm{N}$ during the early part of the Holocene along a west-east transect in the Mediterranean (Magny et al., 2011b), as reflected by the lake-level record of Preola but also by those of Medina in southern Spain (Reed et al., 2001), Xinias in Greece (Digerfeldt et al., 2007), and Gölhisar in southwestern Turkey (Eastwood et al., 2007), as well as by the Soreq isotope record (Bar-Matthews et al., 1998). The latter records show that this explanation may also be applied to the eastern Mediterranean, which is also influenced by the Asian monsoon. However, the African and Asian monsoons are strongly coupled (Fleitmann et al. 2008) through the Hadley cell activity. Indeed, using sensitivity experiments trough a General Circulation Model, Gaetani et al. $(2007,2011)$ have shown how an intense African monsoon reinforces the Hadley circulation, and consecutively strengthens the North Atlantic anticyclone (with a wider extension of the descending branch of the Hadley cell) and its blocking effect for the western (Atlantic) wet air flow towards the Mediterranean. This interpretation is supported by data obtained from marine core ODP site 658 C off Mauritania, which shows the effects of the declining summer insolation maximum as early as ca. $10000 \mathrm{cal} \mathrm{BP}$ at ca. $20^{\circ} \mathrm{N}$ in the eastern North Atlantic area (deMenocal et al., 2000; Berger and Loutre, 1991). Links between a strong monsoon system and an increased summer dryness are also supported by recent observations for the last two millennia in the eastern Mediterranean (Jones et al., 2006). It is worth noting that even the North African lakelevel record (Hoelzmann et al., 1998; Damnati, 2000; Gasse and Roberts, 2004; Lézine et al., 2011) shows such a slightly delayed humidity maximum as do the Preola and Soreq records. In addition, model experiments have shown how the presence of remnant ice sheets (with associated fresh water input into the North Atlantic Ocean and lake drainage episodes) may have 


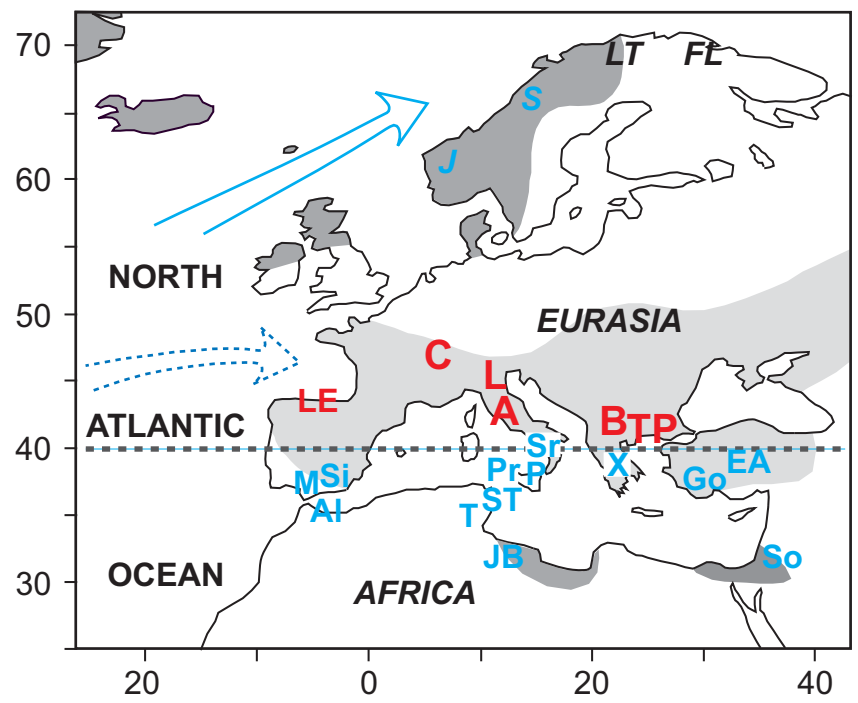

Fig. 8. Positive NAO-like palaeohydrological/palaeoclimatic pattern during the Holocene climatic optimum as suggested by milder (black letters) and wetter (blue letters) versus drier (red letters) climatic conditions around the Mediterranean Basin and in Western Europe. (A) Lake Accesa in central Italy (Magny et al., 2007); Al: core MD95-2043 in Alboran Sea (Fletcher et al., 2013); (B) Boras Mountains in northern Greece (Lawson et al., 2005); (C) Lake Cerin (Magny et al., 2011a); EA: Lake Eski Acigöl in central Turkey (Turner et al., 2008); FL: Finnish Lapland (Seppä et al., 2008); Go: Lake Gölhisar in south-western Turkey (Eastwood et al., 2007); J: Jostedalsbreen in western Norway (Nesje et al., 2000); JB: Jebel Gharbi in north-western Libya (Giraudi et al., 2012); L: Lake Ledro in northern Italy (Magny et al., 2012b); LE: Lake Enol in northern Spain (Moreno et al., 2011); LT: Lake Toskaljavri, Finland (Seppä et al., 2008); M: Lake Medina in southern Spain (Reed et al., 2007); P: Lake Pergusa in Sicily (Magny et al., 2011b); Pr: Lake Preola in Sicily (Magny et al., 2011b); S: Lake Svanåvatnet, northern Norway (Bjune and Birks, 2008); Si: Siles in southern Spain (Carrión, 2002); So: Soreq Cave in southern Israel (Bar-Matthews et al., 1998); Sr: Sele River in southern Italy (Naimo et al., 2005); ST: core MD04-2797 in the Siculo-Tunisian strait (Desprat et al., 2013); T: central Tunisian rivers (Ziehlhofer and Faust, 2008); TP: Tenaghi Philippon in northern Greece (Kotthoff et al., 2008); X: Lake Xinias in northern Greece (Digerfeldt et al., 2007). (Dotted) arrow indicates westerlies in positive (negative) NAO-type circulation in response to weaker (stronger) LTG. The present day areas affected by increasing (decreasing) humidity in response to positive (negative) NAO are represented by dark (light) grey zones (from Lamy et al., 2006; Marshall et al., 2001).

been responsible for a southward shift of the monsoon rain belt, as discussed by Lézine et al. (2011) regarding Holocene palaeohydrological records from the Sahara and Sahel, and provoked dry conditions during the early part of the Holocene. Such an evolution of combined orbital and ice-sheet forcing may have favoured the general delay of the forest expansion observed in the pollen records from Trifoglietti (Joannin et al., 2013), core MD04-2797 in the Siculo-Tunisian Strait (Desprat et al., 2013; Bout-Roumazeilles et al., 2013) and core MD95-2043 in the Alboran Sea (Fletcher et al., 2013), as well as in the eastern Mediterranean region (Roberts et al., 2001; Valsecchi et al., 2012), with west-east and north-south gradients probably due to an increasing distance from the North Atlantic Ocean and from the northern mid-latitude westerlies.

- As discussed above in Sect. 3, contrasting hydrological patterns have been identified in the central Mediterranean south and north of $40^{\circ} \mathrm{N}$. Interestingly, Davis and Brewer (2009) have shown that at the mid-Holocene the latitude around $40^{\circ} \mathrm{N}$ also corresponds to a temperature limit with negative temperature anomalies (climate cooling) to the south and positive values to the north. This may have favoured a positive water balance to the south and a negative one to the north, in agreement with the lake-level records presented in Fig. 3. Furthermore, the final steps of the deglaciation in a general context of high insolation provoked a decrease in the latitudinal temperature gradient (LTG) (not directly in phase with the maximum insolation), and favoured the installation of a positive NAO-type circulation in the North Atlantic area (Davis and Brewer, 2009). Thus, the initiation of the lake-level minimum at Lakes Accesa and Cerin around $9000 \mathrm{cal}$ BP coincided with the disappearance of the Fennoscandian ice sheet (Magny et al., 2011a) and a first installation of a general atmospheric circulation, which mimics a positive NAO-type circulation (Gladstone et al., 2005; Wanner et al., 2008; Dyck et al., 2010). In the south-central Mediterranean, the wide amplitude of the lake-level fluctuations during the unstable transition period 10300-9000 cal BP (see above, Sect. 3.1) may reflect a diminished influence of the Fennoscandian deglaciation period. Finally, the second major step of the deglaciation, with a rapid melting of the Laurentide ice sheet (LIS) between 8000 and $7000 \mathrm{cal} \mathrm{BP}$, punctuated by a marked increase in sea-level rise around 7600 cal BP (Carlson et al., 2008), led to the expansion of a predominant positive NAOtype circulation towards higher latitudes (weaker LTG; Davis and Brewer, 2009). This resulted in warm/humid air advection into northern Europe (northward movement of westerlies), as reflected by the increasing humidity observed in western Norway and the rapid treeline rise in Finnish Lapland around 7500 cal BP (Fig. 6; Bjune and Birks, 2008; Nesje et al., 2000; Seppä et al., 2008). On the basis of palaeoclimatic data, the map in Fig. 8 presents an illustration of the possibly prevailing positive NAO-type circulation over Europe and the Mediterranean and its contrasting palaeohydrological pattern for the middle part of the Holocene. While a decrease in the LTG favoured a northward migration of westerlies which brought milder and wetter climate 


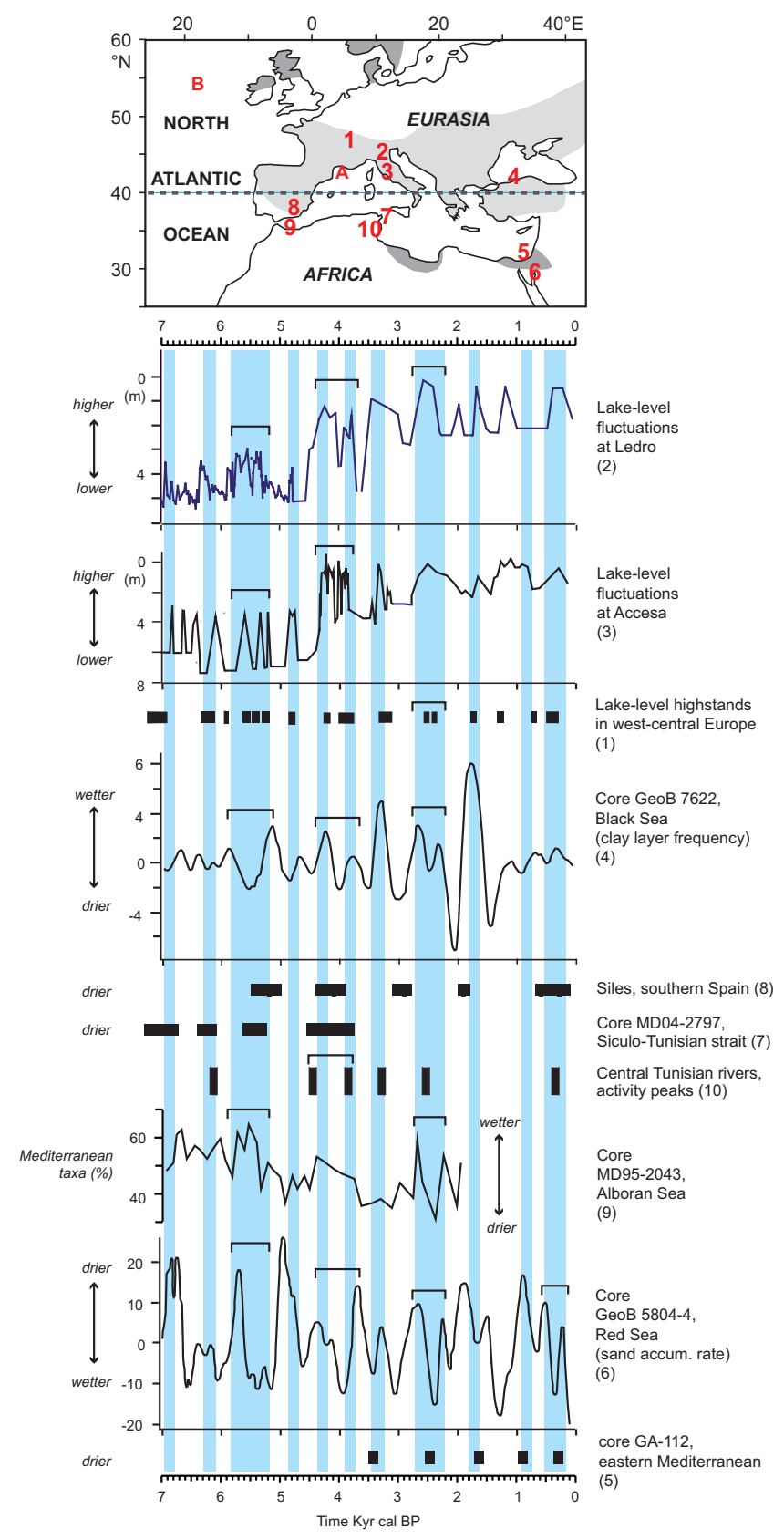

Fig. 9. (Top) Location of records used in the lower panel (1 to 10) or cited in the text (A and B). (1) lake-level record from west-central Europe (Magny, 2013); (2) Lake-level record from Lake Ledro (Magny et al., 2012b); (3) Lake-level record from Lake Accesa (Magny et al., 2007); (4) core GeoB7622 (Lamy et al., 2006); (5) core GA-112 (Schilman et al., 2001); (6) core GeoB5804-4 (Lamy et al., 2006), (7,8 and 9) pollen records from core MD04-2797 (Desprat et al., 2013), from Siles (Carrión, 2002), and from core MD95-2043 (Fletcher et al., 2013), respectively; (10) central Tunisian rivers (Ziehlhofer and Faust, 2008). (A) record of storm frequency from a lagoonal sediment sequence in the Gulf of Lions (Sabatier et al., 2012); (B) IRD record from the North Atlantic Ocean (Bond et al., 2001). The present day areas affected by increasing (decreasing) humidity in response to positive (negative) NAO are represented by dark (light) grey zones (from Lamy et al., 2006; Marshall et al., 2001). (Bottom) Centennial-scale hydroclimatic changes around the Mediterranean basin during the last seven millennia. The numbers in brackets after the names of the sites on the right-hand side of the figure refer to the points located on the map in the upper panel. The Ledro, Accesa and west-central Europe lake-level records are from Magny et al. (2007, 2012b) and from Magny (2013); the records from cores GeoB 7622 and GeoB 5804-4 are from Lamy et al. (2006); the record from Siles is from Carrión (2002); the record from core MD04-2797 is from Desprat et al. (2013), that from central Tunisian rivers is from Ziehlhofer and Faust (2008); the record from core MD95-2043 is from Fletcher et al. (2013); and the record from core GA-112 is from Schilman et al. (2001). Horizontal brackets point out a possible complexity of events (see discussion in the text). 
conditions over northern Europe, the development of more humid conditions in the Mediterranean during the middle part of the Holocene may have resulted from (1) orbital conditions, i.e. decreased summer insolation and reduced blocking effect of the North Atlantic anticyclone for the western (Atlantic) wet air flow towards the Mediterranean; (2) the development of lows induced by stronger sea-land temperature contrasts in winter along the relief of the northern and southern Mediterranean coastlines (Trigo et al., 2002; Harding et al., 2009); (3) sub-Saharan cyclones over the westerncentral Mediterranean (Knippertz, 2005) favoured by a more northerly position of ITCZ during the insolation maximum, as well as rainstorms originating from the Tropics over the eastern Mediterranean (Ziv et al., 2005); and (4) a substantial increase in precipitation in response to generally higher sea-surface temperature (SST) (Marchal et al., 2002).

However, the prevailing positive NAO-type circulation during the middle part of the Holocene remains a matter of debate. The winter mid-latitude circulation and associated storms reaching Europe may have been determined by a complex interplay between the mid-latitude temperature gradient, the tropical convection and the surface contrast at the North American East coast, which have varied along the Holocene due to changes in insolation and ice-sheet extent (Brayshaw et al., 2011). In particular, in order to explain an increased winter precipitation during the $10000-7000 \mathrm{cal} \mathrm{BP}$ interval, Desprat et al. (2013) pointed to a possible southern location of the mid-latitudes jet, strengthening the Mediterranean cyclogenesis, in agreement with model simulations in response to a weaker boreal winter insolation (Brayshaw et al., 2011) and to a rapid LIS melting associated with a suppression of the deep convection in the Labrador Sea and a cooling the eastern North Atlantic (Carlson et al., 2008).

- After ca. 7500 cal BP, the LTG began to increase (Davis and Brewer, 2009) and favoured (1) both the southward migration of the ITCZ and monsoon system, in agreement with the Cariaco record (Haug et al., 2001); and (2) that of the westerlies. However, the records presented in Figs. 6 and 7 suggest that, in response to the progressive decline in insolation and LTG, the climate reversal may have been characterised by abrupt climatic changes. As early as ca. 7500 cal BP, a major climate reversal occurred, as suggested (1) to the south by an abrupt fall in the Nile discharge (Revel et al., 2010; Fig. 7f), and a peak in the eolian dust record of Kilimanjaro due to enhanced aridity (Thompson et al., 2002); and (2) to the north by the development of colder SST in the Norwegian Sea (Fronval and Jansen, 1996) and the beginning of a drying trend at Jostedalsbreen in western Norway (Nesje et al., 2000; Fig. 6, panel e). In the southern Mediterranean, the lake-level records from Preola in Sicily, Medina in Spain, and Xinias in Greece, as well as the oxygen-isotope record from Gölhisar in Turkey, show a marked negative anomaly around $7500 \mathrm{cal}$ BP followed by a general decline in humidity after ca. $6000 \mathrm{cal}$ BP (see Fig. 10 in Magny et al., 2011b). In addition, the Preola sediment sequence gives evidence of a provisional resumption of eolian sand deposition during the dry phase around 7300 cal BP (Fig. 7b), while the Soreq Cave record marks an abrupt fall in wetness after ca. $7500 \mathrm{cal}$ BP. However, the comparison of the Preola and North African lake-level records (Fig. 7f) suggests that the African lakes were more affected by the climatic oscillation around $7500 \mathrm{cal} \mathrm{BP}$ than the Mediterranean ones, while they show nearly synchronous rises in water table around $10500 \mathrm{cal} \mathrm{BP}$. In the northern Mediterranean (Lake Accesa) and in west-central Europe (Lake Cerin), the period around $7500 \mathrm{cal}$ BP coincided with the beginning of a trend toward higher lake-level conditions, while marine core MD90-917 in the southern Adriatic Sea shows a marked decline in salinity around 75007000 cal BP probably due to increased discharge from the Po River in northern Italy (Combourieu Nebout et al., 2013; Siani et al., 2013).

The event around $7500-7000$ cal BP could be a nonlinear response of the climate system to the gradual decrease in insolation. The period around 8000$7000 \mathrm{cal}$ BP appears to be synchronous with a prolonged period of decrease in residual atmospheric ${ }^{14} \mathrm{C}$ developed between ca. 8200 and $7200 \mathrm{cal}$ BP (Stuiver et al., 1998). This interval also coincided with a major final step of the deglaciation, as pointed out by Törnqvist and Hijma (2012), with the glacial lakes of LabradorUngava outburst events (Jansson and Kleman, 2004). Thus, the large magnitude of the event around 75007000 cal BP may have resulted from a combination of three factors, i.e. the orbital forcing (decline in the summer insolation), the final deglaciation, and a change in solar activity.

- The records presented in Figs. 6 and 7 point to a second major event around 4500-4000 cal BP, which marks another key step in the climate reversal following the Holocene climate optimum. It may be considered as the end of the general dominance of positive NAO-type circulation, as suggested by the end of the humid interval in western Norway (Bjune and Birks, 2008), with the marked decline in temperature and in timberline in northern Scandinavia (Fig. 6; Seppä et al., 2008), i.e. all indicators of a southward migration of westerlies and their associated influence for mild/wet climatic conditions. To the south, in Northern Africa, the interval $4500-4000$ cal BP coincided with a major fall in temperature in the Kilimanjaro region (Schmiedl et al., 2010), and corresponded to the most salient event (double peak) in the Holocene eolian dust record of 
Kilimanjaro (Thompson et al., 2002), and to the end of the high lake-level period in the North African lakes (Hoelzmann et al., 1998; Gasse and Roberts, 2004; Kröpelin et al., 2008). In the southern Mediterranean, an abrupt decrease in wetness at Lake Preola and at Soreq Cave developed south of $40^{\circ} \mathrm{N}$. In the northern Mediterranean and in west-central Europe, Lakes Accesa and Cerin show an accentuated rise in lake level. Such an abrupt change in environmental and climatic conditions around $4500 \mathrm{cal} \mathrm{BP}$ has been reconstructed in central Italy (Zanchetta et al., 2012; Ramrath et al., 1999), at Lake Maliq (Magny et al., 2009; Fouache et al., 2010) and at Lakes Prespa and Dojran (Wagner et al., 2010; Francke et al., 2013) in the Balkans. As observed for the climate reversal at ca. $7500-7000 \mathrm{cal} \mathrm{BP}$, this second major climate reversal around 4500-4000 cal BP, which marks the transition between the middle and late Holocene (Walker et al., 2012), may be a non-linear response to a gradual decrease in insolation (Zhao et al., 2010) and LTG. It is worth noting that it also coincided with a key period of seasonal and interhemispheric changes in insolation (Fig. 7) and with a reorganisation of the general atmospheric circulation underlined by a pronounced southward shift of ITCZ in the Tropics (Haug et al., 2001; Magny et al., 2012b). Marchant and Hooghiemstra (2004) and Booth et al. (2005) have shown how this severe climatic anomaly may have been global in extent. In the northern Mediterranean, the rising lake levels probably reflect the increasing influence of westerlies, and instead of drier conditions developed in the southern Mediterranean and the Tropics in response to climate cooling, i.e. lower sea-surface temperature and weaker evaporation (Magny et al., 2003; Mayewski et al., 2004).

\subsection{Centennial-scale events}

According to Davis and Brewer (2009), the LTG controls the location of the main climate zones, as well as the position of the Hadley cell and the ITCZ. Every year, the Hadley cell moves northwards (southwards) in summer (winter) when the LTG is weak (strong). These annual migrations offer modern analogues for mechanisms associated with high-latitude Holocene cooling events and their consequences in terms of wetter (drier) conditions in the subtropics and in northern latitudes when the systems migrate northwards (southwards). In addition to the effects of the system migrations, cooling events also favour a decrease in wetness in southern latitudes due to lower sea-surface temperature and weaker evaporation.

It is well known that the early Holocene has been punctuated by a series of freshwater outbursts from deglacial lakes in northern Europe and in North America, resulting in successive cooling events in the North Atlantic area at ca. 11300 (Preboreal oscillation), 10200, 9200, 8200 and
7500-7000 cal BP (Alley et al., 1997; Björck et al., 1997, 2001; Fleitmann et al., 2008; Magny et al., 2001; Magny and Bégeot, 2004; Jansson and Kleman, 2004; Yu et al., 2010). Authors have also shown how these events may have been associated with cooling in the North Atlantic and have resulted from a possible combination of freshwater outbursts and decrease in solar activity (Magny, 1999, 2004, 2006; Bond et al., 2001; Björck et al., 2001; van der Plicht et al., 2004; Magny and Bégeot, 2004). Palaeohydrological data collected in Europe suggest that the cooling events have coincided at mid-latitudes with wetter climate conditions in response to an increasing strength of the Atlantic westerly jet (increasing LTG), while latitudes south of ca. $40^{\circ} \mathrm{N}$ experienced drier climate conditions (Magny et al., 2003). The cold and dry conditions associated with the interruption of Sapropel 1 during the $8.2 \mathrm{ka}$ event offer a well-known illustration for these mechanisms (Kotthoff et al., 2008; Pross et al., 2009).

Previous studies have revealed possible imprints of deglacial cooling events in the western and central Mediterranean from marine and terrestrial (lacustrine) cores (e.g. Cacho et al., 2001; Asioli et al., 2001; Magny et al., 2006a; Fletcher et al., 2010). Data collected within the LAMA project clearly show how these cooling events in the central Mediterranean corresponded to wetter conditions marked by higher lake levels to the north of ca. $40^{\circ} \mathrm{N}$ and to drier conditions to the south. The drier conditions south of ca. $40^{\circ} \mathrm{N}$ are marked by a retreat of forest taxa in core MD04-2097 at ca. $11300,10100,9300,8200$, and $7000 \mathrm{cal}$ BP (Desprat et al., 2013) (Fig. 5), in good agreement with phases of forest retreat identified from core MD95-2043 in the Alboran Sea (Fletcher et al., 2013).

Regarding the mid- to late Holocene period, Fig. 9 presents a comparison between selected records around the Mediterranean (Fig. 9, upper panel) to test the hypothesis of a possible impact of NAO-type circulation in driving centennial-scale climatic events, as proposed by Lamy et al. (2006). Lake-level records present phases of higher water table (wetter conditions) reconstructed in west-central Europe and in the north-central Mediterranean (Magny, 2013; Magny et al., 2007, 2012b). Records from cores GeoB7622 and GeoB5804-4 have been established by Lamy et al. (2006). Core GeoB7622 in the south-western Black Sea off the Sakarya River mouth gives evidence of variations in the frequency of clay layers which reflect variations in rainfall in northern Anatolia. Core GeoB58044 in the Gulf of Aqaba (northern extremity of the Red Sea) provides a record of terrigenous sand accumulation as a marker of the eolian input (dryness) from neighbouring deserts. Cores GA-112/GA110 off southern Israel have been studied by Schilman et al. (2001) and give evidence of Nile flood fluctuations on the basis of variations in eastern Mediterranean productivity over the last $3500 \mathrm{yr}$. Three pollen records (1) from marine cores MD04-2797 in the Siculo-Tunisian strait (Desprat et al., 2013), (2) MD95-2043 in the Alboran Sea (Fletcher et al., 2013), and (3) from Lake 
Siles in southern Spain (Carrión, 2002) document drought phases in the south-central and south-western Mediterranean. Finally, Fig. 9 shows a series of dry events identified in Central Tunisia from major peaks in fluvial activity linked to a decrease in vegetation cover (Zielhofer and Faust, 2008).

The general picture which emerges from Fig. 9 is that of a succession of centennial-scale climatic oscillations which punctuated the mid- to late Holocene period in the Mediterranean and are associated with contrasting hydrological patterns characteristic of NAO-type circulation, as first hypothesised by Lamy et al. (2006). Thus, within the radiocarbon age uncertainty, phases of increasing wetness in the northcentral Mediterranean and in northern Anatolia appear to be broadly synchronous with phases of increasing dryness in the southern Mediterranean borderlands and reduced Nile flood frequencies. Taken together, these data show a regional pattern coherent with that of the negative phase of NAO. Despite the relatively weak temporal resolution of core MD95-2043 for the late Holocene, this general pattern is supported by the well-dated high-resolution record of Siles, near the Alboran Sea. Davis and Brewer (2009) have shown close relationships between winter LTG across Europe and AO during the 20th century, with positive (negative) AO-type circulation linked to weaker (stronger) LTG. This is consistent with Wanner et al. (2001) and Trouet et al. (2009), which show that during negative NAO phases, the Azores high is weakened, resulting in a southward move of westerlies and an increase in moisture transported over the European midlatitudes. This is supported by the reconstruction of Holocene storm activity in the north-western Mediterranean (Sabatier et al., 2012), in addition to a $200 \mathrm{yr}$ time series of recent Po River discharges, which confirms the link between negative NAO, higher Po discharge and stronger precipitation in northern Italy (Zanchettin et al., 2008). These results, hypothesising a possible major impact of NAO (MO) on the Holocene climate in the Mediterranean, support interpretations from previous studies of the climate oscillation around 4500-4000 cal BP in the central Mediterranean (Magny et al., 2009) or concerning the last millennium in the Mediterranean (Roberts et al., 2011). This points out similar mechanisms such as those described for millennial trends (see above, preceding Sect. 4.2), with cooling events responsible (1) for wetter conditions over the northern Mediterranean more affected by a southward migration of westerlies due to a stronger LTG, and (2) for drier conditions in the southern Mediterranean and the Tropics in response to cooler seasurface temperature and weaker evaporation (Magny et al., 2003; Mayewski et al., 2004).

Moreover, on the basis of spectral analyses, Lamy et al. (2006) have suggested that the marine records from cores GeoB7622 and GeoB5804-4 show a likely solar origin for the AO-NAO like atmospheric variability in the Mediterranean during the mid- to late Holocene. This is supported by correlations identified between (1) phases of high lake-level (or increasing flood frequency) in the north-central Mediterranean and west-central Europe, (2) IRD events in the North Atlantic Ocean, and (3) peaks in atmospheric residual ${ }^{14} \mathrm{C}$ (Bond et al., 2001; Magny, 1999, 2013; Magny et al., 2003, 2007, 2012b; Vannière et al., 2013). Such a relationship is consistent with model studies (Shindell et al., 2001). All together, in agreement with Lamy et al. (2006), this suggests a prominent role of NAO-type circulation and solar forcing in the centennial-scale climate variability in the Mediterranean area during the last seven millennia.

In addition, data presented in Fig. 9 suggest possible latitudinal changes in the limit between the contrasting hydrological sectors in the Mediterranean in response to changing NAO. Thus, during the LIA, fluvial data from Tunisian rivers (Zielhofer and Faust, 2008) and pollen data from the Spanish site of Siles (Carrión, 2002) suggest drier conditions, though pollen data from Pergusa in Sicily (Sadori et al., 2013) give evidence of more humid conditions. During the interval 2700-2300 cal BP, the regions of southern Spain and the Alboran Sea may have been included in the northern hydrological sector characterised by more humid conditions in response to negative NAO as shown by the records from Siles and marine core MD95-2043. This is supported by polleninferred quantitative estimates at Pergusa, Sicily (Sadori et al., 2013) and by the Trifoglietti water-depth record discussed above in Sect. 3.2 (Joannin et al., 2013b), while, in contrast, the Tunisian area belongs to the southern hydrological sector marked by drier conditions (Zielhofer and Faust, 2008). Taken together, available data suggest a southward migration of the limit between the northern and the southern hydrological sectors during the intervals 2700-2300 and 500-200 cal BP (i.e. the LIA) in the central Mediterranean.

Looking at the climate oscillation pattern, the double peaks that appear around $2500 \mathrm{cal}$ BP in cores GeoB58044, MD95-2043 and GeoB7622 may find an equivalent in the two successive lake-level highstands identified in westcentral Europe during this interval (Magny, 2004, 2013). The possible complexity of the oscillation around 43003700 cal BP, well illustrated by the lake-level records of Lakes Ledro and Accesa and of west-central Europe (Magny et al., 2009, 2012a), is also supported by the records from Lake Dojran (Francke et al., 2013) core GeoB7622 in the Black Sea and core GeoB5804-4 in the Red Sea (Lamy et al., 2006), and by a double peak of eolian dust in the Kilimanjaro record (Thompson et al., 2002). However, the pollen data from Siles and core MD95-2043 appear to be conflicting (dryness at Siles and higher humidity in the Alboran Sea region). The lake-level records from Ledro, Accesa and west-central Europe (Magny et al., 2006b) reveal a possible complexity of the oscillation around 57005200 cal BP with three successive events. The pollen- and sediment-records from cores MD04-2797 and GeoB5804-4 also show a possible tripartite pattern but, in core MD042797, the second retreat of Mediterranean tree taxa and the second and third sand peaks in core GeoB5804-4 are weakly marked. Thus, clearly, the schema outlined in Fig. 9 must be 
tested through further investigations to establish additional high-resolution and well-dated records in selected locations around the Mediterranean basin.

\section{Conclusions}

On the basis of a multi-proxy approach and a strategy combining lacustrine and marine records along a north-south transect, data collected in the central Mediterranean within the framework of the LAMA project have led to the reconstruction of palaeohydrological records with specific efforts to establish robust chronologies and attain high temporal resolutions. Several conclusions and working hypotheses emerge from these investigations as follows.

- Lacustrine and marine sediment sequences studied within the LAMA project offer a new contribution to better constrained correlations between tephro- and palaeohydrological/palaeoclimatic stratigraphies.

- South of ca. $40^{\circ} \mathrm{N}$, the first millennium of the Holocene was characterised by very dry climatic conditions, not only in the eastern Mediterranean, but also in the central and the western Mediterranean as reflected by low lake levels and delayed afforestation.

- Contrasting patterns of palaeohydrological changes have been evidenced in the central Mediterranean: north (south) of around $40^{\circ} \mathrm{N}$, the middle part of the Holocene was characterised by lake-level minima (maxima), during an interval dated to ca. $10300-4500 \mathrm{cal} \mathrm{BP}$ to the south and $9000-4500 \mathrm{cal} \mathrm{BP}$ to the north. Available data suggest that these contrasting palaeohydrological patterns operated during the entire Holocene, both on millennial and centennial scales.

- The use of a multi-proxy approach supports the reconstruction of contrasting precipitation seasonality. Thus, the maximum humidity in the central Mediterranean during the middle part of the Holocene was characterised by humid winters and dry summers north of ca. $40^{\circ} \mathrm{N}$, and humid winters and summers south of $40^{\circ} \mathrm{N}$. This may explain an apparent conflict between palaeoclimatic records depending on the proxies used for the reconstruction, as well as a synchronous expansion of tree species with contrasting climatic requirements.

Thus, instead of a west-east opposition often proposed by previous studies, the results obtained within the project LAMA point to north-south contrasts in the Mediterranean Basin. From this point of view, the latitudes around $40^{\circ} \mathrm{N}$ appear to be particularly important but, in the details, the precise location of this limit between north and south hydrological sectors in the Mediterranean area may have fluctuated in time and space. Moreover, the results presented in this paper suggest that the deposition of Sapropel 1 has been favoured by an increase (1) in winter precipitation in the northern Mediterranean borderlands, and (2) in winter and summer precipitation in the southern Mediterranean area.

- The climate reversal following the Holocene climate optimum appears to have been punctuated by two major climate oscillations around 7500 and $4500 \mathrm{cal} \mathrm{BP}$. In addition to previous studies about the $4.2 \mathrm{ka}$ event in the eastern Mediterranean and Tropics, the high-resolution palaeohydrological reconstructions established within the project LAMA reveal a pronounced climatic change around 4500-4000 cal BP in the central Mediterranean, with contrasting changes in the hydrological cycle (drought trend to the south, and more humid conditions to the north). Thus, these new data show the clear climatic (palaeohydrological) significance, for the central Mediterranean, of the formal distinction between the middle and the late Holocene proposed by Walker et al. (2012). However, even if useful, the reference to the $8.2 \mathrm{ka}$ event to distinguish between the early and the middle Holocene does not find a major climatic significance in the central Mediterranean where the maximum (minimum) of summer humidity started around $10500 \mathrm{cal}$ BP (9000 cal BP) in the south- (north-) central Mediterranean.

- Regarding the possible forcing factors, the palaeohydrological changes reconstructed in the central Mediterranean appear to have occurred in response to a combination of orbital, ice-sheet and solar forcing factors. Considering palaeohydrological records along a latitudinal gradient, increasing time lags are evidenced from the Tropics to northern Europe, with maximum (or minimum) of humidity starting as early as the beginning of the Holocene in equatorial Africa and not before 7500 cal BP in northern Norway. Within this general framework, the interval of the humidity maximum in the south-central Mediterranean started at ca. $10300 \mathrm{cal} \mathrm{BP}$, in correlation with the decline of (1) the blocking effects of the North Atlantic anticyclone linked to the maximum of summer insolation and (2) the influence of the remnant ice sheets and fresh water forcing in the North Atlantic Ocean. Its duration until ca. 4500 cal BP broadly coincides with that observed for the high lakelevel status of North African lakes between $8^{\circ}$ and $28^{\circ} \mathrm{N}$. In the north-central Mediterranean, the interval of lake-level minimum began only around $9000 \mathrm{cal}$ BP when the Fennoscandian ice sheet disappeared and a prevailing positive NAO-type circulation developed in the North Atlantic area. The major palaeohydrological oscillation around 4500-4000 cal BP may be a nonlinear response to the gradual insolation decrease in addition to key seasonal and interhemispheric changes in insolation. At a centennial scale, the successive climatic events which punctuated the entire Holocene in the central Mediterranean coincided with cooling events 
associated with decreases in solar activity and deglacial outbursts in the North Atlantic area during the interval $11700-7000 \mathrm{cal} \mathrm{BP}$, and to a possible combination of NAO-type circulation and solar forcing from ca. 7000 cal BP onwards.

Further investigations are still needed to test the conclusions proposed in this paper. It is clear that the hypothesis of a possible influence of a NAO-type circulation operating on a centennial scale appears to be a relevant way to explain contrasting palaeohydrological patterns in the Mediterranean Basin as suggested by available data. However, in addition to possible local effects which bias the climatic signal, the interregional correlations between records and their interpretation in terms of past atmospheric circulation patterns like NAO are often hampered by insufficient temporal resolution and/or chronological controls of the records. These observations should encourage developing new investigations to establish additional palaeohydrological/environmental records based on high-resolution analyses and a robust chronology, and using a strategy favouring a careful selection of study sites locations. In particular, future studies should outline with greater precision, on both millennial and centennial time scales, changes in the latitudinal location of the limit between the northern and southern palaeohydrological Mediterranean sectors, depending (1) on the intensity and/or characteristics of climatic periods/oscillations (e.g. Holocene thermal maximum versus Neoglacial, as well as the $8.2 \mathrm{ka}$ event versus the 4 ka event or Little Ice Age), and (2) on varying geographical conditions from the western to the eastern Mediterranean regions. Finally, on the basis of projects using strategically located study sites, there is a need to develop the exploration of possible influences of other general atmospheric circulation patterns than NAO, such as the East Atlantic-West Russian or North Sea-Caspian patterns, in explaining the apparent complexity of palaeoclimatic (palaeohydrological) Holocene records from the Mediterranean area.

Acknowledgements. Financial support for this study was provided by the French ANR within the project LAMA (MSHE Ledoux, Besançon, France, project ANR-07-BLAN-0009-01, Michel Magny and Nathalie Combourieu Nebout), the French C.N.R.S. (project HotMED-Paleomex in the programme MISTRALS, B. Vannière and M. Magny), and the Swiss National Science Foundation (grant PPOOP2-114886 to W. Tinner). This is the LSCE contribution $n^{\circ} 4591$.

Edited by: D.-D. Rousseau

\section{References}

Alley, R. B., Mayewski, P. A., Sowers, T., Stuiver, M., Taylor, K. C., and Clark, P. U.: Holocene climatic instability: a prominent, widespread event 8200 yr ago, Geology, 25, 483-486, 1997.

Asioli, A., Trincardi, F., Lowe, J. J., Ariztegui, D., Langone, L., and Oldfield, F.: Sub-millennial scale climatic oscillations in the central Adriatic during the Lateglacial: palaeoceanographic implications, Quaternary Sci. Rev., 20, 1201-1221, 2001.

Aufgebauer, A., Panagiotopoulos, K., Wagner, B., Schäbitz, F., Viehberg, F. A , Vogel, H., Zanchetta, G., Sulpizio, R., Leng, M. J., and Damaschke, M.: Climate and environmental change in the Balkans over the last $17 \mathrm{ka}$ recorded in sediments from Lake Prespa (Albania/F.Y.R. of Macedonia/Greece), Quatern. Int., 274, 122-135, 2012.

Bar-Matthews, M., Ayalon, A., and Kaufman, A.: Middle to Late Holocene (6500 yr period) paleoclimate in the eastern Mediterranean region from stable isotopic composition of speleothems from Soreq Cave, Israël, in: Environment and society in times of climate change, edited by: Issar, A. and Brown, N., Dordrecht, Kluwer Academic, 203-214, 1998.

Baroni, C., Zanchetta, G., Fallick, A. E., and Longinelli, A.: Molluscs stable isotope record of a core from Lake Frassino (northern Italy): hydrological and climatic changes during the last $14 \mathrm{ka}$, The Holocene, 16, 827-837, 2006.

Beaulieu de, J. L., Miras, Y., and Andrieu-Ponel, V.: Vegetation dynamics in north-western Mediterranean regions: instability of the Mediterranean bioclimate, Plant Biosystems, 139, 114-126, 2005.

Berger, A.: Long-term variations of caloric insolation resulting from the earth's orbital elements, Quaternary Res., 9, 139-167, 1978.

Berger, A. and Loutre, M. F.: Insolation values for the climate of the last 10 million of years, Quaternary Sci. Rev., 10, 297-317, 1991.

Björck, S., Muscheler, R., Kromer, B., Andresen, C. S., Heinemeier, J., Johnsen, S., Conley, D., Koç, N., Spurk, M., and Veski, S.: High-resolution analyses of an early Holocene climate event may imply decreased solar forcing as an important climate trigger, Geology, 29, 1107-1110, 2001.

Björck, S., Rundgren, M., Ingolfsson, O., and Funder, S.: The Preboreal oscillation around the Nordic seas: terrestrial and lacustrine responses, J. Quaternary Sci., 12, 455-465, 1997.

Bjune, A. E. and Birks, H. J. B.: Holocene vegetation dynamics and inferred climate changes at Svanåvatnet, Mo i Rana, northern Norway, Boreas, 37, 146-156, 2008.

Bond, G., Kromer, B., Beer, J., Muscheler, R., Evans, M. N., Showers, W., Hoffmann, S., Lotti-Bond, R., Hajdas, I., and Bonani, G.: Persistent solar influence on North Atlantic climate during the Holocene, Science, 294, 2130-2136, 2001.

Booth, R., Jackson, S. T., Forman, S. L., Kutzbach, J. E., Bettis, E. E., Kreig, J., and Wright, D. K.: A severe centennial-scale drought in mid-continental North America 4200 years ago and apparent global linkages, The Holocene, 15, 321-328, 2005.

Bout-Roumazeilles, V., Combourieu-Nebout, N., Desprat, S., Siani, G., Turon, J.-L., and Essallami, L.: Tracking atmospheric and riverine terrigenous supplies variability during the last glacial and the Holocene in central Mediterranean, Clim. Past, 9, 10651087, doi:10.5194/cp-9-1065-2013, 2013. 
Brayshaw, D. J., Rambeau, C. M. C., and Smith, S. J.: Changes in Mediterranean climate during the Holocene: insights from global and régional climate modelling, The Holocene, 21, 15-31, 2011.

Cacho, I., Grimalt, J. O., Canals, M., Sbaffi, L., Shackleton, N. J., Schönfeld, J. and Zahn, R.: Variability of the Western Mediterranean sea surface temperature during the last 25000 years and its connection with the Northern Hemisphere climatic changes, Paleoceanography, 16, 40-52, 2001.

Calò, C., Henne, P. D., Curry, B., Magny, M., Vescovi, E., La Mantia, T., Pasta, S., Vannière, B., and Tinner, W.: Spatio-temporal patterns of Holocene environmental change in southern Sicily, Palaeogeogr. Palaeocl., 323/325, 110-122, 2012.

Carcaillet, C., Barakat, H., Panaïotis, C., and Loisel, R.: Fire and late-Holocene expansion of Quercus ilex and Pinus pinaster on Corsica, Vegetation Sci., 8, 85-94, 1997.

Carlson, A. E., Legrande, A. N., Oppo, D. W., Came, R. E., Schmidt, G. A., Anslow, F. S., Licciardi, J. M., and Obbink, E. A.: Rapid early Holocene deglaciation of the Laurentide ice sheet, Nat. Geosci., 1, 620-624, 2008.

Carrión, J. S.: Patterns and processes of Late Quaternary environmental change in a montane region of southwestern Europe, Quaternary Sci. Rev., 21, 2047-2066, 2002.

Colombaroli, D., Tinner, W., van Leeuwen, J., Noti, R., Vescovi, E., Vannière, B., Magny, M., Schmidt, R., and Bugmann, H.: Response of broadleaved evergreen Mediterranean forest vegetation to fire disturbance during the Holocene: insights from the peri-Adriatic region, J. Biogeogr., 1365-2699, 2009.

Combourieu Nebout, N., Peyron, O., Dormoy, I., Desprat, S., Beaudouin, C., Kotthoff, U., and Marret, F.: Rapid climatic variability in the west Mediterranean during the last 25000 years from high resolution pollen data, Clim. Past, 5, 503-521, doi:10.5194/cp5-503-2009, 2009.

Combourieu Nebout, N., Peyron, O., Bout Roumazeilles, V., Dormoy, I., Joannin, S., Sadori, L., and Siani, G.: Central Mediterranean vegetation changes during the Holocene time through the core MD 90-917 pollen record, Clim. Past Discuss., in preparation, 2013.

Damnati, B.: Holocene lake records in the Northern Hemisphere of Africa, J. African Earth Sci., 31, 253-262, 2000.

Davis, B. A. S. and Brewer, S.: Orbital forcing and role of the latitudinal insolation/temperature gradient, Clim. Dynam., 32, 143$165,2009$.

Davis, B. A. S., Brewer, S., Stevenson, A. C., and Guiot, J.: The temperature of Europe during the Holocene reconstructed from pollen data, Quaternary Sci. Rev., 22, 1701-1716, 2003.

deMenocal, P. B., Ortiz, J., Guilderson, T., Adkins, J., Sarnthein, M., Baker, L., and Yarusinski, M.: Abrupt onset and termination of the African Humid Period: rapid climate response to gradual insolation forcing, Quaternary Sci. Rev., 19, 347-361, 2000.

Desprat, S., Combourieu-Nebout, N., Essallami, L., Sicre, M. A., Dormoy, I., Peyron, O., Siani, G., Bout Roumazeilles, V., and Turon, J. L.: Deglacial and Holocene vegetation and climatic changes in the southern Central Mediterranean from a direct land-sea correlation, Clim. Past, 9, 767-787, doi:10.5194/cp-9767-2013, 2013.

Develle, A. L., Herreros, J., Vidal, L., Sursock, A., and Gasse, F.: Controlling factors on a paleo-lake oxygen isotope record (Yammoûneh, Lebanon) since the Last Glacial Maximum, Quaternary Sci. Rev., 29, 865-886, 2010.
Digerfeldt, G., Sandgren, P., and Olsson, S.: Reconstruction of Holocene lake-level changes at Lake Xinias, central Greece, The Holocene, 17, 361-367, 2007.

Drysdale, R., Zanchetta, G., Hellstrom, J., Maas, R., Fallick, A. E., Pickett, M., Cartwright, I., and Piccini, L.: Late Holocene drought responsible for the collapse of Old World civilizations is recorded in an Italian cave flowstone, Geology, 34, 101-104, 2006.

Dünkeloh, A. and Jacobeit, J.: Circulation dynamics of Mediterranean precipitation variability 1948-1998, Int. J. Climatol., 23, 1843-1866, 2003.

Dyck, S., Tremblay, L. B., and de Vernal, A.: Arctic sea-ice cover from the early Holocene: the role of atmospheric circulation patterns, Quaternary Sci. Rev., 29, 3457-3467, 2010.

Eastwood, W. J., Leng, M. J., Roberts, N., and Davis, B.: Holocene climate change in the eastern Mediterranean region: a comparison of stable isotope and pollen data from Lake Gölhisar, southwest Turkey, J. Quaternary Sci., 22, 327-341, 2007.

Fleitmann, D., Burns, S. J., Mangini, A., Mudelsee, M., Kramers, J., Villa, I., Neff, U., Al-Subbary, A. A., Buettner, A., Hippler, D., and Matter, A.: Holocene ITCZ and Indian monsoon dynamics recorded in stalagmites from Oman and Yemen (Socotra), Quaternary Sci. Rev., 26, 170-188, 2007.

Fleitmann, D., Mudelsee, M., Burns, S. J., Bradley, R. S., Kramers, J., and Matter, A.: A Widespread climate anomaly at around 9200 years before present, Paleoceanography, 23, PA1102, doi:10.1029/2007PA001519, 2008.

Fletcher, W. J., Sanchez Goñi, M. F., Peyron, O., and Dormoy, I.: Abrupt climate changes of the last deglaciation detected in a Western Mediterranean forest record, Clim. Past, 6, 245-264, doi:10.5194/cp-6-245-2010, 2010.

Fletcher, W. J., Debret, M. and Sanchez Goñi, M. F.: Mid-Holocene emergence of a low-frequency millennial oscillation in western Mediterranean climate: implications for past dynamics of the North Atlantic atmospheric westerlies, The Holocene, 23, 153166, 2013.

Foerster, V., Junginger, A., Langkamp, O., Gebru, T., Asrat, A., Umer, M., Lamb, H. F., Wennrich, V., Rethemeyer, J., Nowaczyk, N., Trauth, M. H., and Schaebitz, F.: Climatic change recorded in the sediment of the Chew Bahir Basin, southern Ethiopia, during the last 45000 years, Quaternary Int., 274, 25-37, 2012.

Fontugne, M., Paterne, M., Calvert, S. E., Murat, A., Guichard, F., and Arnold, M.: Adriatic deep water formation during the Holocene: implication for the reoxygenation of the deep Eastern Mediterranean sea, Paleoceanography, 4, 199-206, 1989.

Fouache, E., Desruelles, S., Magny, M., Bordon, A., Oberweiler, C., Coussot, C., Touchais, G., Lera, P., Lézine, A. M., Fadin, L., and Roger, R.: DEM and GIS as Tools for palaeogeographical reconstructions of Lake Maliq (Korça Basin, Albania) between 14000 and 2000 BP, J. Archaeol. Sci., 37, 525-535, 2010.

Francke, A., Wagner, B., Leng, M. J., and Rethemeyer, J.: A Late Glacial to Holocene record of environmental change from Lake Dojran (Macedonia, Greece), Clim. Past, 9, 481-498, doi:10.5194/cp-9-481-2013, 2013.

Frisia, S., Borsato, A., Mangini, A., Spötl, C., Madonia, G., and Sauro, U.: Holocene climate variability in Sicily from a discontinuous stalagmite record and the Mesolithic to Neolithic transition, Quaternary Res., 66, 388-400, 2006. 
Fronval, T. and Jansen, E.: Rapid changes in ocean circulation and heat flux in the Nordic Seas during the last interglacial period, Nature, 383, 806-810, 1996.

Gaetani, M., Baldi, M., Dalu, G. A., and Maracchi, G.: Connessioni tra il clima della regione Mediterranea e l'Africa occidentale attraverso la circolazione meridiana di Hadley, in: Clima e cambiamenti climatici, edited by: Carli, B., Cavarretta, G., Colacino, M. and Fuzzi, S., Roma, Consiglio Nazionale delle Ricerche, 23-26, 2007.

Gaetani, M., Pohl, B., Douville, H., and Fontaine, B.: West African monsoon influence on the summer Euro-Atlantic circulation, Geophys. Res. Lett., 38, L09705, doi:10.1002/joc.3615, 2011.

Garcin, Y., Melnick, D., Strecker, M. R., Olago, D., and Tiercelin, J. J.: East African mid-Holocene wet-dry transition recorded in palaeo-shorelines of Lake Turkana, northern Kenya Rift, Earth Planet. Sci. Let., 331-332, 322-334, 2012.

Gasse, F. and Roberts, C. N.: Late Quaternary hydrologic changes in the arid and semi-arid belt of Northern Africa, in: The Hadley circulation: present, past and future, edited by: Diaz, H. F. and Bradley, R. S., Kluwer Academic Publishers, London, 313-345, 2004.

Giorgi, F. and Lionello, P.: Climate change projections for the Mediterranean region, Global Planet. Change, 63, 90-104, 2008.

Giraudi, C.: Late Pleistocene and Holocene lake-level variations in Fucino Lake (Abruzzo, central Italy) inferred from geological, archaeological and historical data, in: Palaeohydrology as reflected in lake-level changes as climatic evidence for Holocene times, edited by: Harrison, S. P., Frenzel, B., Huckried, U., and Weiss, M., Paläoklimaforschung, 25, 1-17, 1998.

Giraudi, C.: Le oscillazioni di livello del Lago di Mezzano (Valentino-VT): variazioni climatiche e interventi antropici, Il Quaternario, 17, 221-230, 2004.

Giraudi, C.: Late Holocene alluvial events in the central Apennines (Italy), The Holocene, 15, 768-773, 2005a.

Giraudi, C.: Middle to Late Holocene glacial variations, periglacial processes and alluvial sedimentation on the higher Apennine massifs (Italy), Quaternary Res., 64, 176-184, 2005b.

Giraudi, C., Magny, M., Zanchetta, G., and Drysdale, R. N.: The Holocene climatic evolution of the Mediterranean Italy: a review of the geological continental data, The Holocene, 21, 105-117, 2011.

Giraudi, C., Mercuri, A. M., and Esu, D.: Holocene palaeoclimate in the northern Sahara margin (Jefara Plain, northwestern Libya), The Holocene, 23, 339-352, 2012.

Gladstone, R. M., Ross, I., Valdes, P. J., Abe-Ouchi, A., Braconnot, P., Brewer, S., Kageyama, M., Kitoh, A., Legrande, A., Marti, O., Ohgaito, R., Otto-Bliesner, B., Peltier, W. R., and Vettoretti, G.: Mid-Holocene NAO: a PMIP2 model intercomparison, Geophys. Res. Lett., 32, L16707, doi:10.1029/2005GL023596, 2005.

Guiot, J.: Methodology of the last climatic cycle reconstruction in France from pollen data, Palaeogeogr., Palaeoclim., 80, 49-69, 1990.

Harding, A., Palutikof, J., and Holt, T.: The climate system, in: The physical geography of the Mediterranean, edited by: Woodward, J., Oxford University Press, 69-88, 2009.

Harrison, S. P. and Digerfeldt, G.: European lakes as palaeohydrological and palaeoclimatic indicators, Quaternary Sci. Rev., 12, 233-248, 1993.
Haug, G. H., Hughen, K. A., Sigman, D. M., Peterson, L. C., and Röhl, U.: Southward migration of the Intertropical Convergence Zone through the Holocene, Science, 293, 1304-1308, 2001.

Hoelzmann, P., Jolly, D., Harrison, S. P., Laarif, F., Bonnefille, R., and Pachur, H. J.: Mid-Holocene land-surface conditions in northern Africa and the Arabian peninsula: a data set for the analysis of biogeophysical feedbacks in the climate system, Global Biochem. Cy., 12, 35-51, 1998.

Hurrell, J. W.: Decadal trends in the North Atlantic Oscillation: regional temperatures and precipitation, Science, 269, 676-679, 1995.

Jalut, G., Esteban Amat, A., Bonnet, L., Gauquelin, T., and Fontugne, M.: Holocene climatic changes in the western Mediterranean, from south-east France to south-east Spain, Palaeogeogr. Palaeoclim., 160, 255-290, 2000.

Jalut, G., Deboubat, J. J., Fontugne, M., and Otto, T.: Holocene circum-Mediterranean vegetation changes: climate forcing and human impact, Quaternary Int., 200, 4-18, 2009.

Jansson, K. N. and Kleman, J.: Early Holocene glacial lake meltwater injections into the Labrador Sea and Ungava Bay, Paleoceanography, 19, 1-12, 2004.

Joannin, S., Brugiapaglia, E., de Beaulieu, J.-L., Bernardo, L., Magny, M., Peyron, O., Goring, S., and Vannière, B.: Pollenbased reconstruction of Holocene vegetation and climate in southern Italy: the case of Lago Trifoglietti, Clim. Past, 8, 1973 1996, doi:10.5194/cp-8-1973-2012, 2012.

Joannin, S., Vannière, B., Galop, D., Peyron, O., Haas, J. N., Gilli, A., Chapron, E., Wirth, S. B., Anselmetti, F., Desmet, M., and Magny, M.: Climate and vegetation changes during the Lateglacial and early-middle Holocene at Lake Ledro (southern Alps, Italy), Clim. Past, 9, 913-933, doi:10.5194/cp-9-913-2013, 2013.

Jones, M. D., Roberts, C. N., Leng, M. J., and Türkes, M.: A highresolution late Holocene lake isotope record from Turkey and links to North Atlantic and monsoon climate, Geology, 34, 361364, 2006.

Knippertz, P.: Tropical-extratropical interactions associated with an Atlantic tropical plume and subtropical jet streak, Mon. Weather Rev., 132, 2759-2776, 2005.

Kotthoff, U., Pross, J., Müller, U. C., Peyron, O., Schmiedl, G., Schulz, H., and Bordon, A.: Climate dynamics in the borderlands of the Aegean Sea during formation of sapropel 1 deduced from a marine pollen record, Quaternary Sci. Rev., 27, 832-845, 2008.

Kröpelin, S., Verschuren, D., Lézine, A. M., Eggermont, H., Cocquyt, C., Francus, P., Cazet, J. P., Fagot, M., Rumes, B., Russell, J. M., Darius, F., Conley, D. J., Schuster, M., von Suchodoletz, H., and Engstrom, D. R.: Climate-driven ecosystem succession in the Sahara: the past 6000 years, Science, 320, 765-768, 2008.

Lamy, F., Arz, H. W., Bond, G. C., Bahr, A., and Pätzold, J.: Multicentennial-scale hydrological changes in the Black Sea and northern Red Sea during the Holocene and the Arctic/North Atlantic Oscillation, Paleoceanography, 21, PA1008, doi:10.1029/2005PA001184, 2006.

Lang, G.: Quartäre Vegetationsgeschichte Europas, Methoden und Ergebnisse, G. Fischer, Jena, 1994.

Lawson, I. T., Al-Omari, S., Tzedakis, P. C., Bryant, C. L., and Christanis, K.: Lateglacial and Holocene vegetation history at Nisi Fen and the Boras mountains, northern Greece, The Holocene, 15, 873-887, 2005. 
Lézine, A. M., Hély, C., Grenier, C., Braconnot, P., and Krinner, G.: Sahara and Sahel vulnerability to climate changes, lessons from Holocene hydrological data, Quaternary Sci. Rev., 30, 30013012, 2011.

Lionello, P., Malanotte-Rizzoli, P., and Boscolo, R.: Mediterranean climate variability, Elsevier, London, 421 pp., 2006.

Lundqvist, J. and Saarnisto, M.: Summary of Project IGCP-253, Quaternary Int., 28, 9-18, 1995.

Magny, M.: Holocene lake-level fluctuations in Jura and the northern subalpine ranges, France: regional pattern and climatic implications, Boreas, 21, 319-334, 1992.

Magny, M.: Reconstruction of Holocene lake-level changes in the Jura (France): methods and results, in: Palaeohydrology as reflected in lake-level changes as climatic evidence for Holocene times, edited by: Harrison, S. P., Frenzel, B., Huckried, U., and Weiss, M., Paläoklimaforschung, 25, Stuttgart, 67-85, 1998.

Magny, M.: Lake-level fluctuations in the Jura and French subalpine ranges associated with ice-rafting events in the North Atlantic and variations in the polar atmospheric circulation, Quaternaire, 10, 61-64, 1999.

Magny, M.: Holocene climatic variability as reflected by midEuropean lake-level fluctuations, and its probable impact on prehistoric human settlements, Quaternary Int., 113, 65-79, 2004.

Magny, M.: Holocene fluctuations of lake levels in west-central Europe: methods of reconstruction, regional pattern, palaeoclimatic significance and forcing factors, Encyclopedia of Quaternary Geology, Elsevier, 1389-1399, 2006.

Magny, M.: Orbital, ice-sheet and possible solar forcing of Holocene lake-level fluctuations in west-central Europe. A comment on Bleicher (2013), Holocene, 23, 1202-1212, 2013.

Magny, M. and Bégeot, C.: Hydrological changes in the European midlatitudes associated with freshwater outbursts from Lake Agassiz during the Younger Dryas event and the early Holocene, Quaternary Res., 61, 181-192, 2004.

Magny, M., Marguet, A., Chassepot, G., Richard, H., and Billaud, Y.: Early and late Holocene water-level fluctuations of lake Annecy, France: sediment and pollen evidence and climatic implications, J. Paleolimnol., 25, 215-227, 2001.

Magny, M., Bégeot, C., Guiot, J., and Peyron, O.: Contrasting patterns of hydrological changes in Europe in response to Holocene climate cooling phases, Quaternary Sci. Rev., 22, 1589-1596, 2003.

Magny, M., de Beaulieu, J. L., Drescher-Schneider, R., Vannière, B., Walter-Simonnet, A. V., Millet, L., Bossuet, G., and Peyron, O.: Climatic oscillations in central Italy during the Last GlacialHolocene transition: the record from Lake Accesa, J. Quaternary Sci., 21, 311-320, 2006a.

Magny, M., Leuzinger, U., Bortenschlager, S., and Haas, J. N.: Tripartite climate reversal in Central Europe 5600-5300 years ago, Quaternary Res., 65, 3-19, 2006b.

Magny, M., de Beaulieu, J.L., Drescher-Schneider, R., Vannière, B., Walter-Simonnet, A. V., Miras, Y., Millet, L., Bossuet, G., Peyron, O., Brugiapaglia, E., and Leroux, A.: Holocene climate changes in the central Mediterranean as recorded by lake-level fluctuations at Lake Accesa (Tuscany, Italy), Quaternary Sci. Rev., 26, 1736-1758, 2007.
Magny, M., Vannière, B., Zanchetta, G., Fouache, E., Touchais, G., Petrika, L., Coussot, C., Walter-Simonnet, A. V., and Arnaud, F.: Possible complexity of the climatic event around $4300-3800 \mathrm{cal}$ BP in the central and western Mediterranean, The Holocene, 19, 823-833, 2009.

Magny, M., Bossuet, G., Ruffaldi, P., Leroux, A., and Mouthon, J.: Orbital imprint on Holocene palaeohydrological variations in west-central Europe as reflected by lake-level changes at Cerin (Jura Mountains, eastern France), J. Quaternary Sci., 26, 171177, 2011a.

Magny, M., Vannière, B., Calo, C., Millet, L., Leroux, A., Peyron, O., Zanchetta, G., La Mantia, T., and Tinner, W.: Holocene hydrological changes in south-western Mediterranean as recorded by lake-level fluctuations at Lago Preola, a coastal lake in southern Sicily, Italy, Quaternary Sci. Rev., 30, 2459-2475, 2011 b.

Magny, M., Peyron, O., Gauthier, E., Vannière, B., Millet, L., and Vermot-Desroches, B.: Quantitativ estimâtes of température and précipitation changes over the last millennium from pollen and lake-level data at Lake Joux, Swiss Jura Mountains, Quaternary Res., 75, 45-54, 2011c.

Magny, M., Arnaud, F., Billaud, Y., and Marguet, A.: Lake-level fluctuations at Lake Bourget (eastern France) around 4500-3500 cal. a BP and their palaeoclimatic and archaeological implications, J. Quaternary Sci., 26, 171-177, 2012a.

Magny, M., Joannin, S., Galop, D., Vannière, B., Haas, J. N., Bassetti, M., Bellintani, P., Scandolari, R., and Desmet, M.: Holocene palaeohydrological changes in the northern Mediterranean borderlands as reflected by the lake-level record of Lake Ledro, northeastern Italy, Quaternary Res., 77, 382-396, 2012 b.

Magny, M., Peyron, O., Sadori, L., Ortu, E., Zanchetta, G., Vannière, B., and Tinner, W.: Contrasting patterns of precipitation seasonality during the Holocene in the south- and northcentral Mediterranean, J. Quaternary Sci., 27, 494-502, 2012c.

Magny, M., Leroux, A., Bichet, V., Gauthier, E., Richard, H., and Walter-Simonnet, A. V.: Climate, vegetation and land use as drivers of Holocene sedimentation: a case study from Lake SaintPoint (Jura Mountains, eastern France), The Holocene, 23, 137147, 2013.

Marchal, O., Cacho, I., Stocker, T., Grimalt, J., Calvo, E., Martrat, B., Shackleton, N., Vautravers, M., Cortijo, E., van Kreveld, S., Andersson, C., Koç, N., Chapman, M., Sbaffi, L., Duplessy, J. C., Sarnthein, M., and Turon, J. L.: Apparent long-term cooling of the sea surface in the northeast Atlantic and Mediterranean during the Holocene, Quaternary Sci. Rev., 21, 455-483, 2002.

Marchant, R. and Hooghiemstra, H.: Rapid environmental change in African and South American tropics around 4000 years before present: a review, Earth Sci. Rev., 66, 217-260, 2004.

Marshall, J., Kushnir, Y., Battisti, D., Chang, P., Czaja, A., Dickson, R., Hurrell, J., McCartney, M., Saravanan, R., and Visbeck, M.: North Atlantic climate variability: phenomena, impacts and mechanisms, Int. J. Climatology, 21, 1863-1898, 2001.

Marshall, M., Lamb, H. F., Huws, D., Davies, S. J., Bates, R., Bloemendal, J., Boyle, J., Leng, M. J., Umer, M., and Bryant, C.: Late Pleistocene and Holocene drought events at Lake Tana, the source of the Blue Nile, Global Planet. Change, 78, 147-161, 2011. 
Mayewski, P. A., Rohling, E. E., Stager, J. C., Karlén, W., Maasch, K. A., Meeker, L. D., Meyerson, E. A., Gasse, F., van Kreveld, S., Holmgren, K., Lee-Thorp, J., Rosqvist, G., Rack, F., Staubwasser, M., Schneider, R. R., and Steig, E. J.: Holocene climate variability, Quaternary Res., 62, 243-255, 2004.

Mercone, D., Thomson, J., Croudace, I. W., Siani, G., Paterne, M., and Troelstra, S. : Duration of S1, the most recent sapropel in the eastern Mediterranean Sea, as indicated by accelerator mass spectrometry radiocarbon and geochemical evidence, Paleoceanography, 15, 336-347, 2000.

Milner, A. M., Collier, R. E. L., Roucoux, K. H., Müller, U. C., Pross, J., Kalaitzidis, S., Christanis, K., and Tzedakis, P. C.: Enhanced seasonality of precipitation in the Mediterranean during the early part of the Last Interglacial, Geology, 40, 919-922, 2012.

Miramont, C., Sivan, O., Rosique, T., Edouard, J. L., and Jorda, M.: Subfossil tree deposits in the Middle Durance (Southern Alps, France): environmental changes from Alleröd to Atlantic, Radiocarbon, 42, 423-435, 2000.

Moreno, A., Lopez-Merino, L., Leira, M., Marco-Barba, J., Gonzalez-Samperiz, P., Valero-Garces, B. L., Lopez-Saez, J. A., Santos, L., Mata, P., and Ito, E.: Revealing the last 13500 years of environmental history from the multiproxy record of a mountain lake (Lago Enol, northern Iberian Peninsula), J. Paleolimnol., 46, 327-349, 2011

Naimo, D., Adamo, P., Imperato, M., and Stanzione, D.: Mineralogy and geochemistry of a marine sequence, Gulf of Salerno, Italy, Quaternary Int., 140-141, 53-63, 2005.

Nesje, A., Lie, O., and Dahl, O. S.: Is the North Atlantic Oscillation reflected in Scandinavian glacier mass balance records?, J. Quaternary Sci., 15, 587-601, 2000.

Orombelli, G. and Mason, P.: Holocene glacier fluctuations in the Italian Alpine region, in Glacier fluctuations during the Holocene, edited by: Harrison, S. P., Frenzel, B., Boulton, G. S., Glaser, B., and Huckrieder, U., Paläoklimaforschung-Paleoclim. Res., 24, 59-65, 1997.

Overpeck, J. T., Webb III, T., and Prentice, I. C.: Quantitative interpretation of fossil pollen spectra: Dissimilarity coefficients and the method of modern analogs, Quaternary Res., 23, 87-108, 1985.

Paterne, M., Guichard, F., and Labeyrie, J.: Explosive activity of the south Italian volcanoes during the past 80000 years as determined by marine tephrochronology, J. Volcan. Geoth. Res., 34, 153-172, 1988

Pausas, J. G.: Changes in fire and climate in the eastern Iberian Peninsula (Mediterranean basin), Clim. Change, 63, 337-350, 2004.

Peyron, O., Goring, S., Dormoy, I., Kotthoff, U., Pross, J., de Bealieu, J. L., Drescher-Schneider, R., and Magny, M.: Holocene seasonality changes in the central Mediterranean region reconstructed from the pollen sequences of Lake Accesa (Italy) and Tenaghi Philippon (Greece), The Holocene 21, 131-147, 2011.

Peyron, O., Magny, M., Goring, S., Joannin, S., de Beaulieu, J.L., Brugiapaglia, E., Sadori, L., Garfi, G., Kouli, K., Ioakim, C., and Combourieu-Nebout, N.: Contrasting patterns of climatic changes during the Holocene across the Italian Peninsula reconstructed from pollen data, Clim. Past, 9, 1233-1252, doi:10.5194/cp-9-1233-2013, 2013.
Pross, J., Kotthoff, U., Müller, U. C., Peyron, O., Dormoy, I., Schmiedl, G., Kalaitzidis, S., and Smith, A. M.: Massive perturbation in terrestrial ecosystems of the Eastern Mediterranean region associated with the $8.2 \mathrm{kyr}$ climatic event, Geology, 37 , 887-890, 2009.

Quézel, P. and Medail, F.: Ecologie et biogéographie des forêts du bassin méditerranéen, Elsevier, coll. Environnement, 571 pp., 2003.

Ramrath, A., Nowaczyk, N., and Negendank, J.: Sedimentological evidence for environmental changes since 34000 years BP from Lago di Mezzano, central Italy, J. Paleolimnol., 21, 423-435, 1999.

Reed, J. M., Stevenson, A. C. and Juggins, S.: A multi-proxy record of Holocene climatic change in southwestern Spain: the Laguna di Medina, Cadiz, The Holocene, 11, 707-719, 2001.

Renssen, H., Seppä, H., Heiri, O., Roche, D. M., Goosse, H., and Fichefet, T. : The spatial and temporal complexity of the Holocene thermal maximum, Nat. Geosci., 2, 411-414, 2009.

Revel, M., Ducassou, E., Grousset, F., Bernasconi, S. M., Migeon, S., Revillon, S., Mascle, J., Murat, A., Zaragosi, S., and Bosch, D.: 100000 years of African monsoon variability recorded in sediments of the Nile margin, Quaternary Sci. Rev., 29, 1342 1362, 2010.

Roberts, N., Meadows, M. E., and Dodson, J. R.: The history of mediterranean-type environments: climate, culture and landscape, The Holocene, 11, 631-634, 2001.

Roberts, N., Jones, M. D., Benkaddour, A., Eastwood, W. J., Filippi, M. L., Frogley, M. R., Lamb, H. F., Leng, M. J., Reed, J. M., Stein, M., Stevens, L., Valero-Garces, B., and Zanchetta, G.: Stable isotope records of Late Quaternary climate and hydrology from Mediterranean lakes: the ISOMED synthesis, Quaternary Sci. Rev., 27, 2426-2441, 2008.

Roberts, N., Brayshaw, D., Kuzucuoglu, C., Perez, R., and Sadori, L.: The mid-Holocene climatic transition in the Mediterranean: causes and consequences, The Holocene, 21, 3-14, 2011.

Roberts, N., Moreno, A., Valero-Garcés, B. L., Corella, J. P., Jones, M., Allcock, S., Woodbridge, J., Morellon, M., Luterbacher, J., Xoplaki, E., and Türkes, M.: Palaeolimnological evidence for an east-west climate see-saw in the Mediterranean since AD 900, Global Planet. Change, 84-85, 23-34, 2012.

Rohling, E. J., Mayewski, P. A., Abu-Zied, R. H., Casford, J. S. L., and Hayes, A.: Holocene atmosphere-ocean interactions: records from Greenland and the Aegean Sea, Clim. Dynam., 18, 587593, 2002.

Rolandi, G., Petrosino, P., and Geehin, J.Mc.: The interplinian activity at Somma-Vesuvius in the last 3500 years, J. Volcanology Geoth. Res., 82, 19-52, 1998

Sabatier, P., Dezileau, L., Colin, C., Briqueu, L., Bouchette, F., Martinez, P., Siani, G., Raynal, O., and Von Grafenstein, U.: 7000 years of paleostorm activity in the NW Mediterranean Sea in response to Holocene climate events, Quaternary Res., 77, 1-11, 2012.

Sadori, L. and Narcisi, B.: The postglacial record of environmental history from Lago di Pergusa, Sicily, The Holocene, 11, 655671, 2001.

Sadori, L., Zanchetta, G., and Giardini, M.: Last Glacial to Holocene palaeoenvironmental evolution at Lago di Pergussa (Sicily, Southern Italy) as inferred by pollen, microcharcoal, and stable isotopes, Quaternary Int., 181, 4-14, 2008. 
Sadori, L., Ortu, E., Peyron, O., Zanchetta, G., Vannière, B., Desmet, M., and Magny, M.: The last 7 millennia of vegetation and climate changes at Lago di Pergusa (central Sicily, Italy), Clim. Past Discuss., 9, 2059-2094, doi:10.5194/cpd-92059-2013, 2013.

Sarikaya, M. A., Zreda, M., çiner, A., and Zweck, C.: Cold and wet Last Glacial Maximum on Mount Sandiras, SW Turkey, inferred from cosmogenic dating and glacier modeling, Quaternary Sci. Rev., 27, 769-780, 2008.

Schilman, B., Bar-Matthews, M., Almogi Labin, A., and Luz, B.: Global climate instability reflected by eastern Mediterranean marine records during the late Holocene, Palaeogeogr. Palaeoclim., 176, 157-176, 2001.

Schmiedl, G., Kunht, T., Ehrmann, W., Emeis, K. C., Hamann, Y., Kotthoff, U., Dulski, P., and Pross, J.: Climatic forcing of eastern Mediterranean deep-water formation and benthic ecosystems during the past 22000 years, Quaternary Sci. Rev., 29, 30063020, 2010.

Seppä, H., MacDonald, G. M., Birks, H. J. B., Gervais, B. R., and Snyder, J. A.: Late-Quaternary summer temperature changes in the northern-Europeaen tree-line region, Quaternary Res., 69, 404-412, 2008.

Shindell, D. T., Schmidt, G. A., Mann, M. E., Rind, D., and Waple, A.: Solar forcing of regional climate change during the Maunder Minimum, Science, 294, 2149-2152, 2001.

Siani, G., Sulpizio, R., and Paterne, M.: Application of marine tephrochronology to paleoclimatic studies : the example of the Central Mediterranean, Acta Vulcanologica, 18, 47-54, 2006.

Siani, G., Paterne, M., and Colin, C.: Late Glacial to Holocene planktic foraminifera bioevents and climatic record in the south Adriatic Sea, J. Quaternary Sci., 25, 808-821, 2010.

Siani, G., Magny, M., Paterne, M., Debret, M., and Fontugne, M.: Paleohydrology reconstruction and Holocene climate variability in the South Adriatic Sea, Clim. Past, 9, 499-515, doi:10.5194/cp-9-499-2013, 2013.

Staubwasser, M. and Weiss H.: Holocene climate and cultural evolution in late prehistoric-early historic West Asia, Quaternary Res., 66, 372-387, 2006.

Stuiver, M., Reimer, P. J., Bard, E., Beck, J. W., Burr, G. S., Hughen, K. A., Kromer, B., McCormac, G., van der Plicht, J., and Spurk, M.: Intcal98 radiocarbon age calibration, 24 000-0 cal BP, Radiocarbon, 40, 1041-1083, 1998.

Thompson, L. G., Mosley-Thompson, E., Davis, M. E., Henderson, K. A., Brecher, H. H., Zagorodnov, V. S., Mashiotta, T. A., Lin, P. N., Mikhalenko, V. N., Hardy, D. R., and Beer, J.: Kilimandjaro ice core records: evidence of Holocene climate change in Tropical Africa, Science, 298, 589-593, 2002.

Tinner, W., van Leeuwen, J. F. N., Colombaroli, D., Vescovi, E., van der Knaap, W. O., Henne, P. H., Pasta, S., D’ Angelo, S., and La Mantia, T.: Holocene environmental and climatic changes at Gorgo Basso, a coastal lake in southern Sicily, Italy, Quaternary Sci. Rev., 28, 1498-1510, 2009.

Törnqvist, T. E. and Hijma, M. P.: Links between early Holocene ice-sheet decay, sea-level rise and abrupt climate change, Nat. Geosci., 5, 601-606, 2012.

Trigo, I. F., Bigg, G. R., and Davies, T. D.: Climatology of cyclogenesis mechanisms in the Mediterranean, Mon. Weather Rev., 130, 549-569, 2002.
Trouet, V., Esper, J., Graham, N. E., Baker, A., Scourse, J. D., and Franck, D. C.: Persistent positive North Atlantic Oscillation mode dominated the medieval climate anomaly, Science, 324, 78-80, 2009.

Turner, R., Roberts, N., and Jones, M. D.: Climatic pacing of Mediterranean fire histories from lake sedimentary microcharcoal, Global Planet. Change, 63, 317-324, 2008.

Tzedakis, P. C.: Seven ambiguities in the Mediterranean palaeoenvironmental narrative, Quaternary Sci. Rev., 26, 2042-2066, 2007.

Tzedakis, P. C., Palike, H., Roucoux K. H., and de Abreu, L.: Atmospheric methane, southern European vegetation and low-mid latitude links on orbital and millennial timescales, Earth Planet. Sci. Lett., 277, 307-317, 2009.

Valsecchi, V., Sanchez Go' ni, M. F., and Londeix, L.: Vegetation dynamics in the Northeastern Mediterranean region during the past $23000 \mathrm{yr}$ : insights from a new pollen record from the Sea of Marmara, Clim. Past, 8, 1941-1956, doi:10.5194/cp-8-19412012, 2012.

van der Plicht, J., van Geel, B., Bohncke, J. P., Bos, J. A. A., Blaauw, M., Speranza, A. O. M., Muscheler, R., and Björck, S.: The Preboreal climate reversal and a subsequent solar-forced climate shift, J. Quaternary Sci., 19, 263-269, 2004.

van Geel, B., Buurman, J., and Waterbolk, H. T.: Archaeological and palaeoecological indications of an abrupt climate change in the Netherlands and evidence for climatological teleconnections around 2650 BP, J. Quaternary Sci., 11, 451-460, 1996.

Vannière, B., Colombaroli, D., Chapron, E., Leroux, A., Tinner, W., and Magny, M.: Climate versus human-driven fire regime in Mediterranean landscapes: the Holocene record of Lago dell'Accesa (Tuscany, Italy), Quaternary Sci. Rev., 27, 11811196, 2008.

Vannière, B., Power M. J., Roberts, N., Tinner, W., Carrion, J., Magny, M., Bartlein, P., and Data Contributors: CircumMediterranean fire activity and climate changes during the mid Holocene environmental transition (8500-2500 cal yr BP), The Holocene, 21, 53-75, 2011.

Vannière, B., Magny, M., Joannin, S., Simonneau, A., Wirth, S. B., Hamann, Y., Chapron, E., Gilli, A., Desmet, M., and Anselmetti, F. S.: Orbital changes, variation in solar activity and increased anthropogenic activities: controls on the Holocene flood frequency in the Lake Ledro area, Northern Italy, Clim. Past, 9, 1193-1209, doi:10.5194/cp-9-1193-2013, 2013.

Vogel, H., Wagner, B., Zanchetta, G., Sulpizio, R., and Rosén, P.: A paleoclimate record with tephrochronological age control for the last glacial-interglacial cycle from Lake Ohrid, Albania and Macedonia, J. Paleolimnol., 41, 407-430, 2010.

Wagner, B., Lotter, A. F., Nowaczyk, N., Reed, J. M., Schwalb, A., Sulpizio, R., Valsecchi, V., Wessels, M., and Zanchetta, G.: A 40,000-year record of environmental change from ancient Lake Ohrid (Albania and Macedonia), J. Paleolimnol., 41, 407-430, 2009.

Wagner, B., Vogel, H., Zanchetta, G., and Sulpizio, R.: Environmental change within the Balkan region during the past ca. $50 \mathrm{ka}$ recorded in the sediments from lakes Prespa and Ohrid, Biogeosciences, 7, 3187-3198, doi:10.5194/bg-7-3187-2010, 2010.

Wagner, B., Aufgebauer, A., Vogel, H., Zanchetta, G., Sulpizio, R., and Damaschke, M.: Late Pleistocene and Holocene contourite drift in Lake Prespa (Albania/F.Y.R. of Macedonia/Greece), Quatern. Int., 274, 112-121, 2012. 
Walker, M. J. C., Berkelhammer, M., Bjorck, S., Cwynar, L.C., Fisher, D. A., Long, A., Lowe, J. J., Newnham, R. M., Rasmussen, S. O., and Weiss, H.: Formal subdivision of the Holocene Series/Epoch: a Discussion Paper by a Working Group of INTIMATE (Integration of ice-core, marine and terrestrial records) and the Subcommission on Quaternary Stratigraphy (International Commission on Stratigraphy), J. Quaternary Sci., 27, 649-659, 2012.

Wanner, H., Brönnimann, S., Casty, C., Gyalistras, D., Luterbacher, J., Schmutz, C., Stephenson, D. B., and Xoplaki, E.: North Atlantic Oscillation: Concepts and studies, Surv. Geophys., 22, 321-382, 2001.

Wanner, H., Beer, J., Bütikofer, J., Crowley, T. J., Cubasch, U., Flückiger, J., Goose, H., Grosjean, M., Joos, F., Kaplan, J. O., Küttel, M., Müller, S. A., Prentice, C., Solomina, O., Stocker, T. F., Tarasov, P., Wagner, M., and Widmann, M.: Mid- to late Holocene climate change: an overview, Quaternary Sci. Rev., 27, 1791-1828, 2008.

Wanner, H., Solomina, O., Grosjean, M., Ritz, S. P., and Jetel, M.: Structure and origin of Holocene cold events, Quaternary Sci. Rev., 30, 3109-3123, 2011.

Wulf, S., Kraml, M., Brauer, A., Keller, J., and Negendank, J. F. W.: Tephrochronology of the $100 \mathrm{ka}$ lacustrine sediment sequence of Lago Grande di Monticchio (southern Italy), Quaternary Int., 122, 7-30, 2004.

Xoplaki, E.: Climate variability over the Mediterranean, PhD, University of Bern, Switzerland, 2002.

Yu, S.-Y., Colman, S. M., Lowell, T. V., Milne, G. A., Fisher, T. G., Breckenridge, A., Boyd, M., and Teller, J. T.: Freshwater outburst from Lake Superior as a trigger for the cold event 9300 years ago, Science, 328, 1162-1266, 2010.
Zanchetta, G., Borghini, A., Fallick, A. E., Bonadonna, F. P., and Leone, G.: Late Quaternary palaeohydrology of Lake Pergusa (Sicily, southern Italy) as inferred by stable isotopes of lacustrine carbonates, J. Paleolimnol., 38, 227-239, 2007a.

Zanchetta, G., Drysdale, R. N., Hellstrom, J. C., Fallick, A. E., Isola, I., Gagan, M. K., and Pareschi, M. T.: Enhanced rainfall in the western Mediterranean during deposition of sapropel 1: stalagmite evidence from Corchia cave (Central Italy), Quaternary Sci. Rev., 26, 279-286, 2007b.

Zanchetta, G., Sulpizio, R., Roberts, N., Cioni, R., Eastwood, W. J., Siani, G., Caron, B., Paterne, M., and Santacroce, R.: Tephrostratigraphy, chronology and climatic events of the Mediterranean basin during the Holocene: an overview, The Holocene, 21, 33$52,2011$.

Zanchetta, G., Giraudi, C., Sulpizio, R., Magny, M., Drysdale, R. N., and Sadori, L.: Constraining the onset of the Holocene "Neoglacial" over the central Italy using tephra layers, Quaternary Res., 78, 236-247, 2012.

Zanchettin, D., Traverso, P., and Tomasino, M.: Po River discharges: a preliminary analysis of a 200-year time series, Clim. Change, 89, 411-433, 2008.

Zhao, C., Yu, Z., and Zhao, Y.: Holocene climate trend, variability, and shift documented by lacustrine stable-isotope record in the northeastern United States, Quaternary Sci. Rev., 29, 1831-1843, 2010.

Zielhofer C. and Faust D.: Mid- and Late Holocene fluvial chronology of Tunisia, Quaternary Sci. Rev., 27, 580-588, 2008.

Ziv, B., Dayan, U., and Sharon, D.: A mid-winter, tropical extreme flood-producing storm in southern Israel: synoptic scale analysis, Meteorology Atmos. Phys., 88, 53-63, 2005. 